Florida International University FIU Digital Commons

$12-1983$

\title{
Labor turnover : its causes, consequences, and control strategy in five selected restaurants in the Miami area
}

Anthony Odey Agbeh

Florida International University

DOI: $10.25148 /$ etd.FI13101535

Follow this and additional works at: https:// digitalcommons.fiu.edu/etd

Part of the Hospitality Administration and Management Commons, and the Labor Relations Commons

\section{Recommended Citation}

Agbeh, Anthony Odey, "Labor turnover : its causes, consequences, and control strategy in five selected restaurants in the Miami area" (1983). FIU Electronic Theses and Dissertations. 1164.

https://digitalcommons.fiu.edu/etd/1164 
LABOR TURNOVER: ITS CAUSES, OONSEQUENCES, AND CONTROL STRATEGY

IN FIVE SELECTED RESTAURANTS

IN THE MIAMI AREA.

by

Anthony odey Agbeh

FLORIDA INTERNATIONAL UNIVERISITY 
ABSTRACT

LABOR TURNOVER: IT CAUSES, CONSEQUENCES, AND CONTROL STRATEGY IN FIVE SELECTED RESTAURANTS IN THE MIAMI AREA.

The purpose of this study is to identify and analyze the basic causes of food service employee turnover in five selected restaurants in the Miami area. The withdrawal behavior in this study is treated in terms of controllable turnover, for the purpose of management, learning more about what action to take to solve this problem which has eaten into the fabric of the hospitality industry.

The aim is to find out from the food service employees and management view of work for the purpose of identifying the variables which cause an employee to voluntarily leave a job.

The objective is therefore, to analyze and describe the problem of labor turnover in these selected restaurants. Such description must precede efforts to arrive at solutions to the problem if these efforts are 
ever to be more than haphazard and superficial.

Sigmund Freud once stated:
"The true beginning of scientific activity consists in describing phenomena and only then in proceeding to group, classify and correlate them." 1

The nature of the study is basically descriptive survey. Data is collected by the use of management questionnaire, food service employee questionnaire and finally employees job description index.

${ }^{1}$ Julian Simon, Basic Research Methods in Social Science. Random House, New York, 1969, p.53. 
The survey consisted of a series of well defined questions with open and closed endings dealing with employee with employee turnover. As Robert Ferber and P. $\mathrm{J}$. Verdoom state in their book titled Research Method in Economics of Business:

"Structured questionnaires, by supplying question formulations in very specific terms as well as the different possible answers are easier for the sample members to answer and also serve to reduce the danger of interviewer bias.

The answers to the prepared questionnaire by sample members were then recorded. The results of the questionnaire responses were then compiled for presentation and analysis.

2 Robert J. Ferber and P.J. Verdoon, Research Methods in Economics and Business, The McMillan Company, 1962 , p. 209 . 
A STUDY OF FOOD SERVICE EMPLOYEE TURNOVER AS SEEN BY MANAGEMENT AND FOOD SERVICE EMPLOYEES IN FIVE THEME RESTAURANTS IN THE MIAMI AREA.

by

\title{
Anthony 0. Agbeh
}

\author{
A thesis submitted in partial fulfillment of \\ the requirements for the degree of \\ MASTER OF SCIENCE \\ in \\ HOTEL AND FOOD SERVICE MANAGEMENT \\ at \\ FLORIDA INTERNATIONAL UNIVERSITY
}

Committee in charge:

$$
\begin{aligned}
& \text { Professor Michael Hurst Chairperson } \\
& \text { Professor Charles Ilvento }
\end{aligned}
$$

December 1983 
To Professors: Michael Hurst

$$
\text { Charles Ilvento }
$$

This thesis, having been approved in respect to form and mechanical execution, is referred to you for judgement upon its substantial merit.

Dean Anthony A. Marshall

School of Hospitality Management

The thesis of Anthony 0 . Agbeh is approved.

Professor Michael Hurst

Professor Charles Ilvento

Date of Examination: December 1983. 
A STUDY OF FOOD SERVICE EMPLOYEE TURNOVER AS SEEN BY MANAGEMENT AND FOOD SERVICE EMPLOYEE IN FIVE THEME RESTAURANTS IN THE MIAMI AREA.

by

Anthony O. Agbeh

A thesis submitted in partial fulfillment of the requirements for the degree of

MASTER OF SCIENCE

in

HOTEL AND FOOD SERVICE MANAGEMENT

at

FLOR IDA INTERNATIONAL UNIVERSITY

1983 


\section{ACKNOWLEDGEMENTS}

I would like to express my sincere appreciation to Professors Michael Hurst and Charles Ilvento, School of Hospitality Management, Florida International University, for their guidance and assistance during the course of this study.

A special thanks to Professor Hurst for acting as Chairperson and whose recommendations during various stages of this study proved most valuable.

A special word of thanks to my parents for their constant encouragement and support during this period of study

Thanks also to Amanda \& Victor Delgadillo who did the final typing. 
TABLE OF CONTENTS

PRELIMINARIES . . . . . . . . . . . $\frac{\text { Page }}{i}$

ACKNOWLEDGEMENTS . . . . . . . . . . i i

SECTION

I. THE PROBLEM AND ITS SETTING . . . . 1

The Statement of the Problem : . 1

The First Sub-Problem . . . . 1

The Second Sub-Problem . . . . 1

The Hypothesis . . . . . . . 1

The First Hypothesis . . . . 1

The Second Hypothesis . . . . 1

The Delimitations........ 1

The Definition of Terms . . . . 2

The Assumptions . . . . . . . 3

The Importance of the Study . . . 3

II. THE REVIEW OF THE RELATED LITERATURE Introduction . . . . . . . . . . 7

Factors Responsible for Turnover. 8

III. THE DATA AND THE TREATMENT OF THE DATA

The Criteria for the

Admissibility of the Data . . . 38

The Research Methodology . . . 38

Specific Treatment of the Data
for each Sub-Problem ...... 42

The Data Needed.......... 42

The Location of the Data . . . . 42

The Means of Obtaining the Data. 43

The Treatment of the Data . . . 43

How the Item Analysis will

be made ............ 43

The Data Needed . . . . . . . 44

The Location of the Data. . . . . 44

The Means of Obtaining the Data . 45

The Treatment of the Data . . . 45

IV. GENERAL PROCEDURES

General Overview . . . . . . 46

Collecting the Data...... 46 
V. THE RESULT

General Overview ....... . 48

The Test of the Hypothesis . . . 48

Hypothes is I. . . . . . . . 48

Hypothesis II . . . . . . . . 48

VI. CONSEQUENCES

59

VII. MEASUREMENTS OF EMPLOYEE TURNOVER

VIII. CONTROL STRATEGIES

IX. SUMMARY, CONCLUSIONS, RECOMMENDATIONS

APPENDIX A A . . . . . . . . . . . . 95

APPENDIX B . . . . . . . . . . . 96

BIBLIOGRAPHY . . . . . . . . . 100

REFERENCES .............. 102

VITA ............... 103 
SECTION I

THE PROBLEM AND ITS SETTING 


\section{SECTION I}

I. The statement of the Problem.

A study to identify and analyze the basic causes of food service employee turnover in five theme restaurants in the Miami area as seen by management and employee.

The statement of the Subproblem

Subproblem I. To identify the basic causes for food service employee turnover.

subproblem II. To analyze the causes for food service employee turnover.

The Hypothesis.

The first hypothesis is that food service employee turnover is due to a variety of reasons.

The second hypothesis is that the most important cause for turnover is failure to properly select employees.

The Delimitations.

The study is limited to restaurants. The study is limited only to five theme restaurants in the Miami area. The study is strictly geared to food service employees. 
Definition of Terms.

Theme Restaurants. "The decoration style of the restaurant and style service related to the menu."*

Food service employee. In this study food service employee include waitress/waiters, cooks, bartender, salad person, busboys and dishwashers.

Turnover. The degree of individual movement across the membership boundary of a social system.

Promotion. The degree of potential vertical occupational mobility within an organization.

Dismissal. This is an example of involuntary turnover.

Resignation. An example of involuntary turnover.

Voluntary turnover. This is individual movement across the membership boundary of a social system which is initiated by the individual example "quit."

Involuntary turnover. An individual movement across the membership boundary of a social system, initiated by the organization e.g. dismissal, layoff and retirement.

*Dewitt C. Coffman. "Marketing for a Full House," Cornell University Ithaca, New York, 1972, p.276. 
Controllable Turnover. Is the avoidable loss of personnel available because management action could have been taken to reduce or prevent such loss-the loss being the result of an interaction between the characteristics of the employee and the employing organization.

\section{Assumptions.}

The first assumption is that Management and food service employees answers to questions will be fair.

The second assumption is that if Management does not take necessary steps turnover rate amongst food service employees will continue to be high.

The Importance of the study.

The problem of employee turnover has been studied by various organizations yet little has been done in house with the result of these studies. Much of this inattention may have been due to the past availability and low cost of hospitality industry labor. The costs of programs and solutions have been viewed by management as greater than the costs of the problem itself. The balance of this cost is rapidly shifting due to a tight labor market and rapidly increasing costs of labor. A closer look is therefore necessary in examining the costs of turnover.

There are generally three basic costs involved, as a result of turnover, cost of lost investment, this is loss of the expenditure actually made to acquire and develop an 
individual and bring him into the organization. Included in this would be cost of recruiting, selecting, hiring, and training, each of these is becoming increasingly important and expensive in the hospitality industry. In terms of human resource accounting management may consider this investment as equivalent to the book value of a physical asset that is found on the balance sheet. The replacement cost of turnover is the monetary sacrifice that would have to be incurred today if the organization were to replace an individual with another capable of rendering an equivalent set of services. It is the cost that would have to be incurred in the present market. Their replacement costs, as well as the hidden costs of turnover, which most operators would rather not want to incur makes it an issue.

\section{Opportunity Cost}

The third major type of cost incurred as a result of turnover is opportunity cost. This is cost of the opportunity foregone to utilize an individual service. The result of their loss is a decrease in productivity and a decrease in the department's capacity to satisfactorily handle the volume of business while replacements are being recruited and trained, such cost are a major loss of revenue that should be controlled to increase profitability. 
These cost could be reduced without large expenditures, because employee turnover is the result of job satisfaction, managerial practice effective supervision, sensitivity to individual aspirations all inexpensive to adjust, will eventually improve employee morale. To offset the rising cost employee turnover is to be given proper attention.

Restaurants that experience high turnover rates are usually in constant state of flux and turmoil. The formal and informal relationships that exist between co-workers and their managers as well as the way people do their jobs all change when someone leaves an establishment and replacement enters.

The way the establishment functions is weakened because of lack of communication, and disrupted because of routine tasks, especially jobs that require coordination.

This study will therefore identify and analyze the basic causes of food service turnover, such analysis will precede efforts to arrive at solutions to the problem if these efforts are ever to be more than haphazard and superficial. 


\section{SECTION II}

THE REVIEW OF THE RELATED LITERATURE 
II. THE REVIEW OF THE RELATED LITERATURE.

There is an immense literature about organizational turnover and its consequences.

The literature begins about 1900, describing various types of organizations, focusing on manufacturing firms, and examines all types of occupations, emphasizing on blue collar workers.

The study of labor turnover can not be treated without relating to the factors and variables that are responsible for turnover.

The review of the literature indicates that the causes of labor turnover are due to a multiplicity of factors stemming from factors considered to be items external to the individual, such as pay and benefits, working conditions, co-workers, and supervision. Other factors include those associated with employee's personal characteristic such as age, length of service and family, and lastly factors tied to the employee's reaction to the job, such as job satisfaction, involvement and expectation. Each of these factors will be discussed in a separate way to show how these affect labor turnover. 
Poor Selection and Hiring Process:

There are various deficiencies in the selection process that can lead to turnover problems. Organizations prepare job specifications that have no value. These specifications may be unrealistic or unclear and thus obsolete. Few managers take the time to think about the kinds of employees who are likely to be successful in and satisfied with a specific job. Managers employ workers on attributes unrelated to job success and overlook necessary requirements. This is further aggravated by managers failure to document selection mistakes. According to Roseman from his finding he notes:

"When business is high it is difficult to recruit candidates and there is pressure to fill a job quickly, managers often lower their job qualifications and assume a high risk by hiring marginal candidates." 1

These workers may be "warm" when hired but later they turn "cold."

Most managers have a tendency of hiring stereotypes. They select candidates who "look good" height, age, weight, social affiliation, criteria unrelated to performance are therefore assigned undue importance.

It is true that objective valid data are necessary in any selection process, but these data are not an end in itself, but a means to an end, they serve as a substitute

${ }^{1}$ Edward Roseman. Managing Employee Turnover: A Positive Approach. Amacom, New York, p. 79 . 
for judgement. In most cases, test do not differentiate well among qualified candidates, because some essential qualities in job applicants cannot be tested. Roseman notes that some managers will commonly say:

"I have really hired a winner. Her test scores were over $85 . " 2$

Another area where selection affects labor turnover is in interviewing. Interviewing well is not a justification for hiring. In most cases managers hire candidates on the basis of superficial first impression. Unfortunately, proficiency in interviewing is not related to performance.

Most managers consider the time invested in selection an extra burden on an already overburdened workload. They reluctantly "fit in" time for developing job specifications, interviewing and carrying out the other steps in the selection process. When they participate in these selection activities, their minds are elsewhere. The result therefore will be to shorten the time invested in the selection process, thereby compromising the quality of their hiring decisions.

With the above observations it is clear that there are many areas where managers are prone to making selec- 
tion errors. These selection errors in the final analysis are directly related to turnover problems.

\section{Inadequate Supervision:}

Fleishman and Harris study and other studies indicate that turnover is substantially high among employees whose supervisors are considered inconsiderate of employee's needs. Fleishman and Harris investigated the relationship between the leader behavior of industrial supervisors and two primary indices of group behavior: labor grievances and employee turnover. They use consideration and structure as two constructs of leadership behavior and indicated "low consideration and high structure go with high grievances and turnover." 3

Supervisors with inflexible work style have a high turnover rate. These supervisors turn away employees because they fail to adapt their leadership style to the needs of subordinates they are supervising and the demands of the situation. They either underlead or overlead, and by this they frustrate and alienate subordinates.

\footnotetext{
${ }^{3}$ Edward A. Fleishman and Edwin F. Harris, "Pattern of Leadership Behavior Related to Employee Grievances and Turnover," Personnel Psychology (Spring 1982), p.43.
} 
Supervisors who are indecisive might prolong certain decisions that might be detrimental to the organization as well as employees. Subordinate, have individual needs and desire and want this to be recognized. A supervisor who gives all subordinate "equal treatment under the auspicies of fairness is causing problems."

These characteristics of nonsupportive supervisors can have a major impact on turnover. Yet organizations often support "high turnover" supervisors for a much longer time than it should be, the rational being that he's done a pretty good job for the organization, and we did not realize how much damage he was doing. According to Roseman he states that:

"No organization can afford supervisors who drive away valuable employees. To accept them is dangerous, to ignore them is fool hardy, and to support them doesn't make any sense at a11." 4

This inadequate or poor supervision causes employees to give up during the "breaking-in period."

Poor Communication:

Instrumental communications is the degree to which information about the job is transmitted by an organization.

${ }^{4}$ op.cit., p.134. 
Most employees feel insecure when they are kept in the dark. They want to be kept abreast on a continually bases on where they stand and what is happening in the establishment. Supporting a negative impact of instrumental communication on turnover is the influential work of Lawler, he states "high feedback about what is accomplished satisfies employees and produces low turnover." 5

A supervisor who is secretive by not informing the employees on what is happening in the establishment makes the subordinates fill information gaps with rumors and gossips, which add to their insecurity. A supervisor's communication deficiencies can hinder employee's job performance, leading to unrest and dissatisfaction. The impact of a supervisor's non-communicativeness was described to Roseman by one employee as follows:

\footnotetext{
"My boss never told me what to do, and I had to mudle along by myself. Naturally, because I had insufficient training and experience, I made mistakes. Yet my boss would never accept any blame for my mistakes. She gave me low performance ratings and minimal salary increases. Yet she was actually surprised when I said I was quitting." 6
}

\footnotetext{
${ }^{5}$ Edward Lawler, Motivation in Work Organization, Monterrey, California, Brooks/Cole, 1973.

${ }^{6}$ op.cit., p.131.
} 
Dr. Farrell in his study of front office communications old and new distinguished between the group directed and manager-controlled formal communication, according to Farrell.

\begin{abstract}
"In group directed system, the indices of employees lack of commitment and motivation i.e. annual employee turnover rate, annual lost time per employee, average number of grievances per employee were significantly lower than those in the managerial controlled system." 7
\end{abstract}

\title{
Lack of Participation
}

The literature on participation can be found in discussions of centralization and autonomy. When organizations are highly centralized, employees have a low degree of participation when employee exercise a high degree of autonomy, their participation is high. Porter and steers (1973) indicate that high participation result in low turnover. Peltman notes that (pp. 48-49).

"The greater the individual participation in job assignment the lower the turnover rate. Participation in job assignment is one form of power concerning the job." 8

7 Thomas Farrell, "Front office Communication: old and New," The Cornell Hotel and Restaurant Administration Quarterly, May 1973.

${ }^{8}$ B. O. Peltman, Some Factors Influencing Labor Turnover: A Review of Research Literature. Ind. Relations, p. 48-61, 1973. 
Participation is portrayed as having influence on turnover indirectly through job satisfaction, which in turn, influences intent to say. Wickert in his investigation of turnover and morale among several groups of young women employees of a telephone company discovered that the turnover was significantly related to the employee feeling of ego-involvement in day to day operation of the company. wickert states that:

\begin{abstract}
"Turnover can be considered an index of morale, these results lead further support to the growing evidence that psychology of egoinvolvement and participation provides an important and valuable approach to the understanding of employee morale."9
\end{abstract}

Falcone study of four departments in a large industrial organization discovered facts to support his hypothesis that:

\begin{abstract}
"Subordinate satisfaction with immediate supervision will be directly related to the frequency of subordinate participation in decision making." 10
\end{abstract}

He also stated that it was not only the quality of subordinate participation in decision making but also the quality that appears to be important.

${ }^{9}$ Fredrick R. Wickert, "Turnover and Employee Feelings of Ego Involvement in Day to Day Operations of a Company." Personnel Psychology (summer 1951), p.185.

10 Raymond L. Falcone. "Credibility qualifier of subordination Participation." The Journal of Business Communication (Spring 1973), p.43. 
Inadequate Pay and Benefits:

It can not be gained said that pay rates can influence turnover. People do leave companies for "more money." People who are paid exceptionally well are probably less likely to leave an organization than people who are not well paid. However, managers have so often overestimated the significance of pay. Studies and literature do reveal that pay is less important to a certain group of employees than to others. The reason pay factor is overestimated by managers is probably because many employees claim they are leaving the organization for "more money" but most of the time pay is used as a covering for other concerns and problems. Although from company to company, the difference in absolute amount of pay (salary, bonus, and benefits) for comparable jobs is relatively low - yet employees in one organization may be quite dissatisfied with the compensation program, while employees in comparable jobs in other establishments, making similar salaries and wages are satisfied. It is true of course that the way the compensation program is administered can contribute to employee's satisfaction.

Most organizations are secretive about salary levels. Employees do have a way of finding out how much his fellow worker makes. They keep track. Compare their wages 
for the same work with their co-workers. As narrated by Roseman thus:

"When a red faced employee confronts a super-
visor and say, 'Joe is making more money than
I am for the same job.' He is concerned about
equitability. Probably the employee has men-
tally compared his own skills responsibil-
ities, performance, and effort with those of
the co-worker and concluded that he is as
good as' or better than the co-worker."ll
In most cases such comparisons are based on ill information and are distorted by personal feelings. Most employees, most of the time look better to themselves than others, by rationalizing their shortcomings. Most employees feel the only way to respond to financial pressure is to get another job that pays more. In most cases, however, these employees don't consider the long term consequences of getting another job, allowing short-term financial problems to compromise their careers.

Automatic salary increases, makes employee aware that they deserve the raise, except they have fouled in the previous months, such automatic increase policy may lead employees to conclude, it doesn't pay to do a good job. Managers do deemphasize merit salary procedures, they change the salary structure of distribution, giving more money to some employees and less to others. This behavior 
can be supported by Roseman findings, one manager did express this feeling to Roseman:

"I have good relationship with all the people who work for me. I know they all try to do a good job. I feel that if I did not encourage the low performers and by passed their salary increases, they would only perform worse. On the other hand, if I took the money gained by not giving some employees salary increases and gave it to the high performers, they would not perform any better. Instead, everybody gets a salary increase. The low performers receive somewhat less, and the high performers receive somewhat more."12

There are other studies which reveal the negative relationship between pay and turnover, Pencavel, for instance notes that:

"The depressing effect of the level of wages on quits seem well established. Wages and quits, of course correspond respectively to our 'pay' and 'turnover.'"13

This model states that pay influences turnover indirectly through job satisfaction and intent to stay.

12 op.cit., p.110.

${ }^{13}$ Pencavel, John H. An Analysis of the Quite Rate in American Manufacturing Industry (Princeton, N.J.), Industrial Relations Section, Department of Economics, Princeton University. 
Job Satisfaction Problems

The significant literature on job satisfaction employee turnover is well summarized in an article by Lyman porter and steers. The article entitled organizational work, and personal factors in employee turnover and absenteeism. They had four categories in the work environment in which factors can be found that affect withdrawal and among these include inter alia: job satisfaction, work environment, job content and personal. There were sufficient evidence given in their research to conclude that importance influences on turnover can be found in each of the named categories. their summaries is as follows:

\begin{abstract}
"Some of the more central variables related to turnover are organization wide in their derivation e.g. pay and promotion policies, while others are to be found in the job content e.g. nature of job requirement and finally, some are centered around the person himself, e.g. age, sex, and length of service. Thus, based on these findings, the major roots of turnover appears to be fairly widespread throughout the various facets of organizational structure as they interact with particular types of individuals." 14
\end{abstract}

The relationship of job satisfaction and turnover, as is considered in this paper, is well described by Vroom, when he states:

14 L.W. Porter and R.M. Steers, "Organizational, Work and Personal Factors in Employee Turnover and Absenteeism." Psychological Bulletin, 1973, 80, pp.151176 . 
"Forces on a person to leave his present position are assumed to be function of the valence of outcomes which cannot be attained without leaving his position (the valence of other positions) and of the expectancy with these other outcomes can be attained. It seems reasonable to assume that simultaneous measurements of the valence of one's present position (i.e. job satisfaction), the valence of the other positions, and the expectancy that these other positions can be attained would yield a better prediction of the outcome of an individuals decision to stay or resign from his job than would measurements of job satisfaction alone." 15

The study conducted by Barnas Dunnetl and Arvey was based on the role of employee expectation, at the time of hire, as they related to later job experiences and turnover. Porter and steers described this study, as follows:

"In both studies, no significant differences were found to exist at the time of entry between the expectation levels of those who remained and those who later decided to leave. However, as time went on, significant differences did emerge, those who remained generally felt their original expectations were essential met on the job, while those who left felt their expectations had not been met." 16

\footnotetext{
${ }^{15}$ victor Vroom, Work and Motivation, John Willeys and Sons, Inc., New York, 1964, p.129. ${ }^{16}$ porter, p. 153.
} 
Emphasis on job satisfaction as a precursor of turnover, had been the frame of reference used in most studies, the question that often arises is how valid is it? Job satisfaction does account for a limited amount of the variance in turnover according to Mobley, job satisfaction is an important factor in the casual chain of events leading to turnover.

When job satisfaction decreases, employees begin increasingly to think about leaving. Their mind will be to go and look for another job alternative. The literature on job satisfaction and turnover consistenly supports the concept of equity theory in that it is usually the perceived equity of pay and compensation rather than their actual amounts that is more important in employee job satisfaction. It is not the job that does not satisfy employee needs, it prevents employees from satisfaction from involvement with family and community.

Some investigation concerning job satisfaction and withdrawal include a study by Charles Hulm (1966).

The Hulm study used the job description index as a measure of job satisfaction levels. He investigated the impact of job satisfaction on turnover among female clerical workers. In the first phase of his study, Hulm established mean satisfaction scores and specific job attitudes scores using the job description index. The 
turnover rate among the subjects was $30 \%$ at the beginning of the study. After the intial data was collected, the company instituted new policies in the areas of salary administration, and promotional opportunities. Hulm readministered the job description index at the end of the study satisfaction scores on four of the five index scale rose significantly between the first and second studies. The turnover rate for the sample dropped from 308 during the first part of the study to 128 during the second. Labor market conditions during this period were the same.

\section{Poor Work Environment}

Literature on the size of the work units and turnover was conducted by Porter and Lawler in 1965. Their conclusions were supported and states that turnover was greater in large units than in small ones. Porter and Lawler concluded their review by stating:

"Increases in size could result in lower ground cohesiveness, higher task specialization and poorer communications. Such results could make it more difficult to fulfill one's expectations, resulting in increased dissatisfaction that would lead to increased tendencies to withdraw."17

${ }^{17}$ Porter, p. 159 
Employee's perception of the work environment vary, there is a certain type of work climate that is unhealthy, for many employees and that may even force them out of the organization.

The values of an establishment are reflected in the behavior of its managers. A common company value that can lead to turnover is don't pamper employees, give them only what you must. other values include focus your attention on the work group, not on individuals; thereby sacrificing individual needs for the good of the group; although this might be as reasonable approach but leads to disgruntled employees. Another value that can create an unhealthy work climate and thus lead to turnover is "don't trust subordinates' if you don't watch them carefully, they will take advantage of you." This creates a closed work environment, characterized by suspicion, coldness, and guardedness. Employees start feeling they are under surveillance and become outer concerned about what they say or do.

When employees are under extreme pressure, relationships are strained, and the work environment can become inhospitable. Crisis, shortfalls, deadlines, bottlenecks, competitive threats all create pressures that disrupt smooth working relationships. A work environment that encourages adversary relationships drives away employees. 
When employees believe that they are not getting a fair share of rewards, status, workload, or opportunities, the work environment becomes inhospitable. Even though managers are committed to "equal treatment" for all subordinates, some subordinates will still feel managers are unfair.

Job Content:

The role of task repetitiveness, job autonomy and responsibility and role clarity have been documented in their relationship to withdrawal behavior.

Increased job specialization in industry has resulted in increased cost through increased absenteeism and turnover while the aim was solely to reduce operating costs. Hospitality industry may promote itself to labor, as having jobs that are interesting, creative and personalized, than those of manufacturing companies to mention but one.

The literature which supports specialization proportion implicitly treats job satisfaction as an intervening variable. Increased specialization (routinization decreases job satisfaction through job stress which, in turn increases turnover). 
Lack of Integration

"Is the degree to which an individual has close friends among organizational members." 18

Integration is a characteristic of individuals (the number of close friends at work.) Van der Merwe and Miller $(1971,1973)$ clearly stated the significance of integration in their important work on turnover.

They stated that:

"A major need satisfier is likely to be that of belonging to a cohesive and rewarding group, and if this need is not satisfied, the worker will very likely fail to adjust to the work situation and will therefore more readily withdraw from it." 19

Van der Merwe and Miller add that the formation of group ties is very likely to be of overriding importance, particularly in the first few months of employment. Their major assumption is that major satisfactions which are likely to differentiate one job from another are those to be found in interpersonal contacts in the working group. According to Merwe and state if a worker's need for belonging to a cohesive and rewarding group is not satisfied, then he is unlikely to adjust to the work situation and will more readily withdraw form it. The relationship between group relationships and turnover is summarized by

$18 \mathrm{James} L$. Price, and Charles w. Mueller. Professional Turnover. The Case of Nurses, Department of Sociology, University of Iowa, Iowa, p. 15.

${ }^{19}$ Van der Merwe and Sylvia Miller, Labor Turnover in the South African Footwear Industry, (Grahamston: Leather Industries Research Institute Res. Bull. 535). 
Van der Merwe and Miller, as follows:

"Satisfying interactions are unlikely in groups which are temporary in nature, and are constantly in a state of erosion and replacement as a result of high labor turnover. Satisfying group interaction, the, will depend upon the existence of stable groups which are cohesive in character, and facilitate positive relationships among members. New employees will more easily integrate into such groups, thus providing replacements for inevitable losses among longer-service workers, and maintaining the stability of the group. By contrast a circular effect is evident in high turnover groups where the lack of a stable case results in poor integration of the newcomer, and high short-term losses, so that few pass on to become long-service workers who may provide a stable case in the future." 20

This discussion shows labor turnover to be both a result and a cause of unsatisfactory integration between the employee and the work group.

Lack of Promotion

"The degree of potential vertical occupational mobility within an organization." 21

${ }^{20}$ Van der Merwe and Syliva Miller, "The Measurement of Labor Turnover." Human Relations, Volume 24, Number 3 , p. 239 .

21 Van der Merwe and Sylvia Miller, p. 
Lack of promotion and chances for advancement, with typical complaints including lack of recognition and curtailed authority and responsibility produces turnover. Most studies on turnover consider promotion opportunities as an objective variable because it refers to the actual possibility for an individual to get ahead in an organization. Whenever an employee is ready for promotion and the number of available openings are out of balance turnover increases. Anyone who has been passed by for promotion naturally feels disappointed, in the interest of "getting ahead," the employee would move from one organization to another. Employees under such conditions feel the longer they remain in a state of readiness without receiving advancement, the more likely they are to become discontent, this problem is prevented in large organizations where advanced positions are held by long-term, older employees who have settled into their jobs.

Promotion not only affects the employees directly involved-other workers are also affected if an older employee is passed by for promotion. The allolder employees may feel that they are dead-ended. When unqualified employees are promoted, more qualified employees may believe, rightly or wrongly, that they are in disfavor and would probably be better off in another organization. 
There are some literature which indicate that promotion is negatively related to turnover meaning, the more the promotional opportunity the less the turnover. Porter and steers 1973, observed the following "promotional considerations often appear to represent significant factors in the termination decision." 22

Sometimes a valuable employee is thrust in a new job prematurely. The subsequent problems in the performance of the job may weaken the self confidence and lower his standing in the eyes of collegues. The result, is he may be forced out of the organization or he may decide to leave voluntarily to get a fresh start. This promotion may lead to dissatisfaction for both employees who are promoted and those who are not promoted affect everyone in the organization, not just the people directly involved.

Employees do feel embarrass and guilt at their lack of growth and at "falling behind" co-workers. Certainly they experience disappointment and frustration. Employees who feel concerned that their personal growth is blocked are candidates for voluntary turnover. Employees who are unconcerned about their growth may become candidates for involuntary turnover. When employees no longer grow on the job, it becomes increasingly difficult for them to

$$
22 \text { op.cit., p.48. }
$$


maintain interest and commitment. So if the employees don't leave voluntarily, their performance may slacken to the point where remedial action has to be taken. Personal development may become an acute issue when employees work under supervisors who are uninterested in offering development assistance - or who are even opposed to developing subordinates.

When employees have limited opportunities for learning and development, concern with lack of career advancement intensifies and may lead to turnover.

Personal Factors

A lot of literature have reported studies that have investigated the predictability of turnover based on individual difference. This individual employee characteristic include among others age, length of service, sex and family responsibility.

(a) Age and Length of service. Increase age and turnover have been found to have a negative relationship (Bassett, 1967).

Younger members of an organization usually have a higher rates of turnover than older members. There is substantial literature which supports a negative relationship between age and turnover. According to Price:

\footnotetext{
"Younger members, for instance have higher rates of turnover than older members because they--the younger members--usually have the most routine jobs, participate little in deci-
} 
sions making, lack knowledge about their jobs, have fewer close friends, receive less pay and have few local obligations to kin."23

Price goes on to say "it is not age itself that produces variation in turnover, but the variables commonly associated with age which include routinization, integration, pay, and instrumental communication." Turnover decreases with increasing age, the argument behind this is that the older the employee is, the more important are job security (Clarke 1950) and benefits accruing to longer services-e.g. pension rights, and thus the lower is the turnover rate.

Harris' review illustrates that "young workers are heavily represented among the leaver's heavily represented in this context, meaning disproportionately represented. "Leaver" being one type of turnover. In her view therefore age are negatively related.

Members with low length of service usually have higher rates of turnover than members with high lengths of service. One might think length of service and turnover indicate the same phenomenon, but such is not the case. The empirical generalization according to price is that:

"During a given period, those who leave the organization are likely to be found disproportionately from among the members with low length of service in the organization. Individual with high lengths of service also 
leave the organization, but their rate of leaving is less than the rate of leaving of individuals with low length of service." 24

Porter and steers note (p. 167) that "increased tenure and propensity to remain." The classical article by Ross on industrial feudalism, he notes (p.912) that most workers who quit their jobs are low in service. Ross' review indicates a negative relationship between length of service and turnover. The length of service and age generalizations are consistent with each other. Since members with low lengths of service are probably younger than members with high lengths of service, it would be expected that low length of service and young members would have higher rates of turnover than high length of service and old members.

Sex - Despite management's commonly held view that female turnover rate is higher than that of males, the evidence is conflicting and will remain so until more systematic investigation is attempted. Different studies have different opinions as to male and female turnover rates.

Most American studies, does reveal that male employee exhibit higher turnover rates than female employees (Myer

24 Ibid., p. 23 . 
and MacLaurin 1943, higher male turnover rates have been reported in a few British studies). (Klein, 1961; Hotel and catering EDC, 1969). On the contrary majority of Australian, Swiss, and British studies purport to support the opposite hypothesis, that female turnover rate is higher than male. In a study of seven grammar schools in the Midlands it was found that the turnover rate of male grammar-school teachers was 98 compared with 138 for women grammar-school teachers (Behrend, 1955). Most of these studies in order to give a clear indication of female and male turnover rate must use the sex variables with standardization and also take cognizance of the different categories of married-single and full-time-part-time. For example, the turnover rate of married women have been shown to be higher than those of single woman (Klein, 1961; Sobel and Wilcock, 1955).

The family variable on turnover cannot be overly emphasized. This can be considered on the two related variables of family size and responsibilities. Although the impact of these factors is changing with traditional work roles between men and women.

"Evidence has been found in studies such as those of Fleshiman and Berniger 1960, and Robinson, 1972. Older women whose children are either grown or require less attention consistently demonstrated lower termination rates 
than their younger counterparts. The present trend indicate that women will be less inclined to spend time away from the workplace due to family responsibilities. The extent to which this will affect organizations remain to be demonstrated.

Level of Employment

Many studies show that turnover is related to the level of employment. When unemployment increases, employee quits and resignation slackens. Conversely, as unemployment decreases (that is jobs are easy to find) employees quits and resignations increases.

Hedberg's Codification exemplifies the nature of this findings. He notes that (p.29);

"Labor turnover varies directly with several measures of employment and indirectly with measures of unemployment." 25

Hedberg's clearly indicates that level of employment and turnover are positively related. Many reviews support the relationship between level of employment and turnover. Moffat and Hill note that "Separation rates - drop when the demand for labor slackens."

The view that turnover level slackens as unemployment rate rises, because employees under this situation have

25 Mafnus Hedberg, The Turnover in Industry An Actuarial Study, Acts Sociological, 5:129-43. 
fewer other jobs alternatives was further contradicted by the recent studies made by Wesmuth and Davis, they state;

"Turnover increased despite sustained high levels of unemployment in the local economy. Turnover reminded low or decreased at two hotels in a market with low unemployment level." 26

other studies that support the notion that level of employment is a variable of turnover include those of a British study over the period $1966-71$ it was stated:

"That turnover for all manufacturing industries, for both males and females was high during the period late 1968 to early 1979. Prior to this period turnover had been comparatively low for period of approximately one year. Since early 1970 turnover rates have fallen to a five year minimum, a fact which might be suspected to be associated with the recent increases in unemployment levels. Indeed turnover rates for males and females show a correlation with unemployment of 0.54 and 0.409 respectively (Wild and Dawson, 1972, p.9.). 27

opportunity is the availability of alternative jobs in the organization's environment. Opportunity with regards to this paper can be viewed in the areas of "supply and demand," pull, economic conditions, and business cy-

${ }^{27}$ William J. Wasmuth and W. Stanley Davis. "Managing Employee Turnover: Why Employee Leave." The Cornell Quarterly, May 1983.

${ }^{26}$ G.W. Moffatt, and Kate Hill, "Labor Turnover in Australia." A review of research, Part 1 Personnel Practice Bull. 26:142:49. 
cles, and state of economy. Opportunity refers to a property of the organization's environment and is commonly measured by the number of job vacancies, the greater the opportunity, and the greater the amount of unemployment, the less the opportunity. Opportunity's positive impact on turnover is supported by a substantial body of literature. March and Simon studies states that "when jobs are plentiful, voluntary movement is high, when jobs are scarce, voluntary turnover is small." 28

This clearly indicates that increases in opportunity produce increase in turnover. The literature supporting the positive impact of opportunity on turnovers makes two assumptions. First, it is assumed that the members of the organization have knowledge about the alternative jobs in the environment. Mattila, for instance, notes that "at least 50 to 60 percent of all workers line up their new jobs" have knowledge about the opportunity available to them. 29

Another assumption is the members of the organization have the freedom to enter and leave the organization. Restrictions on this freedom in some countries is typical-

\footnotetext{
${ }^{28}$ op.cit. p. 13

${ }^{29}$ Ibid., p.14.
} 
ly imposed by the government as when in June, 1940, all the workers in the Soviet Union were frozen in their jobs (Fainsod 1963, p.107). In countries where there is no restriction the assumption is empirically sound. Simon and March commented when they ranked in their discussion of the causes of turnover, they clearly stated that in absence of systematic empirical evidence, opportunity is the most important cause of turnover.

Hospitality Industry Turnover:

The major problem in the hospitality industry, which has an effect on cost and productivity is that of employee turnover. In the hospitality industry turnover exceeds that of general industry. Some figures do quote turnover in the hospitality industry as being 10.4 percent per month or about 125 percent per year.

According to Wasmuth and Davis:

"Employee turnover rates in the hospitality industry, it is generally agreed, are as high as or higher than in any other industry. "30

Despite these studies, it is surprising that relatively little attention is being given to managing em-

${ }^{30}$ William J. Wasmuth and $W$. Stanley Davis. Cornell Quarterly February 1983, p.15. 
ployee turnovers inspite of the fact that most operators are struggling to maintain profit margins.

The result of the hospitality industry's inattention to the study of its own employee's needs has been alarmingly high, and has brought about high rate of labor turnover. A National Manpower survey which contacted 3,800 individual establishments employing over 220,000 persons concluded that:

\begin{abstract}
"The food service industry had a voluntary quit and a rate of hiring employees which were both well in excess of that of all manufacturing industries. The voluntary quit rate of $7 \%$ per month and the accession rate of 10.48 per month extended to annual rates would indicate that of the 12.48 of the new employee hired each year, 848 will voluntarily leave their position." 31
\end{abstract}

There are different kinds of cost involved in turnover among some of these include the replacement costs, as well as the hidden cost of turnover, this makes it an important issue most operators would not want to deal with.

In Restaurant and Institution of December 1982 job survey respondents from various segments of the food service industry were asked about their annual labor turnover according to Roxanne their findings was he noted:

${ }^{11}$ A study of career Ladders and Manpower Development for Non-Management personnel in the Food Service Industry. Office of Manpower Research, U.S. Department of Labor, June 1970 , p. 4. 
"Dishwashers have the highest rate of turnover, with weighted means of 418 . Hotels report a turnover rate of 598 while cafeteria's experience a turnover rate of $36 \%$. The industry experienced 268 rate for chief/cooks. Waitress jobs have the second highest turnover rate, with an average of 398. Fine-dining restaurants report a turnover rate of slightly less than average, at $37 \%$ and medium price operations have slightly higher rate of $418 . " 32$ 


\section{SECTION III}

THE DATA AND THE TREATMENT OF THE DATA 


\section{SECTION III}

III. The Data and the Treatment of the Data

The date of this research are of two kinds; primary and secondary data. The nature of each of these two types of data will be given briefly below.

The primary data - the primary data will consist of the response by sample managers and employees who have been affected by turnover in five theme restaurants in Dade County. The secondary data - the secondary data includes, Library research published studies and texts and the unpublished dissertations and thesis dealing with employee turnover.

The Criteria for the Admissibility of the Data

only those questionnaires fully completed will be used in this study. The responses by managers and employees who have worked in restaurants for at least one year were considered.

The Research Methodology

The researcher intends to determine what is actually happening at the moment. The survey method will be used for the gathering of primary data.

As Leedy indicates - the survey method does two things for the researcher; the first is making the re- 
searcher look at the population closely and second, he makes records of his observations.*

Denning states certain basic steps to take in planning the survey and these include:

(1) Define the problem statistically and decide the information needed.

(2) Define your universe.

(3) Investigate to see how much of the needed information is already available in other reports.

(4) Decide on the type of survey.

(5) Lay plans for reducing the burden of response.

(6) Lay out several alternative sample designs.

(7) Provide samples that will measure completeness of coverage, effects on errors, difference from various, procedures of collecting and difference in cost between various procedures.

(8) Draw up instruction for field workers.

(9) Get started on tabulation plans and finalize them.

(10) Pre-test the questionnaires.

(11) Revise the questionnaires.

(12) Finalize the sampling procedure. 
(13) Carry out the survey and tabulations

(14) From subsample of the return compute the sampling.

(15) Interpret and publish the result. 33

In order to obtain the needed primary data for this project, the descriptive survey method would be used because of its accuracy and efficiency. The descriptive survey method involves observing the population which falls within research parameters and recording what is observed for analysis.

This analysis will give an insight to the proposed problems. Data must be presented systematically so that valid and accurate conclusions may be drawn.

The data calls for the solicitation of opinions of managers and employees of selected theme restaurants in the Miami area. To get their opinion, survey questionnaires will be distributed and collected personally by the researcher within the shortest possible time.

By using this method of gathering the primary data a high percentage of response to the questionnaires is expected.

${ }^{3}$ paul Denning Leedy. Research Methodology, New York: Prentice-Hall, Inc. $1978, \frac{\text { p.97. }}{\text { p. }}$ 
A number of writers have responded to the method of descriptive survey used in previous studies to this one:

"There is a risk in inferring the actual level
of satisfaction and dissatisfaction from de-
scription of events by individuals.
Individuals may be more likely to perceive the
cause of satisfaction within the self and
hence describe experiences involving their own
achievement, recognition or advancement in
their job. On the other hand, they may be at-
tributed dissatisfaction, not to personal
indadequacies or deficiencies, but to factors
in the work environment i.e. obstacles pre-
sented by company policies and supervision." 34

However, inspite of its deficiencies, this researcher feels that the descriptive survey method is the best to be use, considering the objectives, circumstances and dimensions of this study.

The initial contacts with the restaurants were made by telephone. During the telephone conversation, the purpose and method of the researcher was explained to the individual and permission was obtained to submit the surveys at a later date.

In the hospitality industry according to wasmuth and Stanley they state "The estimated cost of turnover ranging form $\$ 5,000$ to $\$ 8,500$. The average overall cost estimated $\$ 2,300$ per turnover. The average cost of $\$ 2,500$ is a rea-

${ }^{34}$ U.H. Uraam and N.R.F. Maler, "Industrial School of Psychology," Annual Review of Psychology, December 1977, p. 36 . 
sonable basis for determining the dollar implication of turnover on the bottom line in the hospitality industry. 35

In order to obtain useful results, the questions where well though out in advance and covered all segments of the related literature.

Specific Treatment of the Data for Each Subproblem:

Subproblem one: The first subproblem is to identify the basic causes for food service employee turnover.

The Data Needed:

The data needed for subproblem one would be responses to the question of the questionnaire that relate to the causes of food service employee turnover.

\section{The Location of the Data:}

The data is located in the response to the questions that are in the questions answered by managers and food service employees. These responses are found within the population of managers and food service employees at selected theme restaurants chosen for this study.

${ }^{35}$ Wasmuth and Davis, "Managing Employee Turnover: Why Employees Leave," Cornell Quarterly, February 1983, p. 22 . 
The Means of Obtaining the Data:

Data will be obtained by means of questionnaires; Appendix A contains a copy of the questionnaire that was distributed. Before the questionnaires were distributed verbal permission was obtained.

\section{The Treatment of the Data:}

How the data will be screened. The completed questionnaires when collected will be screened to eliminate only questionnaires where all the questions are not fully answered or where managers and food service employees has not been an employee for a year as to participate in this study •

How the Item Analysis Will Be Made:

The analysis of this study is the identifying of factors that cause food service employee turnover in theme restaurants.

The most relevant causes of food service employee turnover are:

working conditions

job insecurity

lack of advancement

lack of motivation 
lack of merit promotion

salary and benefits

lack of motivation

not getting along with managers

got a better job

commuting distance

too long hours

school.

Subproblem two: the second subproblem is to analyze the causes affecting turnover of food service employee in theme restaurants.

\section{The Data Needed}

The data needed for the solving of subproblem two would be the responses to the questions of the questionnaire that relate to food service employee turnover in theme restaurants in the Miami area.

The Location of the Data:

The data is located in the response to the questions that are in the questionnaires answered by managers and food service employees. These responses are found within the population of managers and food service employees in selected theme restaurants. 
The Means of Obtaining the Data:

The responses of the criteria will be obtained by means of questionnaires. Appendix A contains a copy of the questionnaire that was distributed. Before the distribution of the questionnaires, verbal permission was obtained.

The Treatment of the Data:

How the data will be screened.

The compiled questionnaires, when collected, will be screened to eliminate any questionnaires where all the questions are not fully answered or where the front office employee has not been an employee long enough to participate in the study.

How the item will be made and interpreted.

The data will be interpreted by counting the number of highest and lowest responses and arriving at a percentage of the total to provide an accurate picture of the causes of food service employee turnover in the hospitality industry. 
SECTION IV

GENERAL PROCEDURE 


\section{GENERAL PROCEDURE}

To initiate the project, the researcher contacted managers of the selected restaurants. The purpose of the survey and reasons for selection of their particular restaurant was explained to them. Almost all the managers agreed to volunteer their employee to participate.

A primary research data was gathered by means of a questionnaire (Appendix $A, B \& C$ ). The questionnaire was pretested in an effort to insure the adequacy of design and established a relative case in completing and responding to the questions.

The researcher went to each of the restaurants on Friday and Saturday at 3:00 PM for a span of two weeks. This time and days was chosen because the researcher believed there would be more employees in the restaurant and the time is the slow period where employees and managers have less work.

The questionnaire was handed personally to managers and food service employees who had worked in the operation for a year or more.

The questions were well-defined with open and closed endings dealing with employee turnover.

Robert Ferber and P.J. Verdoon stated in their book, 
47

Research Methods in Economics and Business:

"Structured questionnaire, by supplying queston formulations in very specific terms as well as the different possible answers, are easier for the sample members to answer and also serve to reduce the danger of interview bias." 36

For this thesis, the survey questionnaires were distributed and collected personally to insure a definite responge, as the population sample was unknown.

36

Robert J. Ferber and P.J. verdoon, Research Methods in Economics and Business, The MacMillan Company, 1962 , p. 209 . 
SECTION V

THE RESULT 


\section{THE RESULT}

Sample members of the population were surveyed by use of detailed questionnaires. Two surveys were administered, one on June 10, 1983, and the second on July 26, 1983. A total of 20 and 80 responses were received from management and food service employees respectively. The test of the hypothesis

Hypothesis I. The first hypothesis is that food service employee turnover is due to a variety of reasons. This hypothesis was supported and accepted by both management and food service employees as displayed on Table 1 and 2. The most reasons mentioned by both management and food service workers include working conditions, pay and benefit selection and hiring practice and conflict with supervisors. See Tables 1 and 2 (Pages $55 \& 56$ ).

Hypothesis II: The second hypothesis is that the most important cause for turnover is failure to properly select and hire employees.

This hypothesis was accepted and is proved on Table 4 ( See page 58) of twelve causal factors of employee turnover selection and hiring came first among the factors with $16 \%$.

Majority of the managers mentioned that employees going back to school or finishing school and starting a new career was a major factor in their own operation. 


\section{TABLES}


When asked what was the percentage of employee turnover in their operation, 9 of the 20 managers responded that it was less than $30 \%$. Five managers stated that their turnover rate was between $30-50 \%$ and 6 managers stated between 50-708.

When asked of turnover rate compared to the industry average only 158 of the managers survey stated that their rate was above average, $40 \%$ stated that it was average, 358 stated below average, while 108 did not respond to this question. Of the managers survey, $60 \%$ stated that they are presently taking steps to monitor the turnover rate, $30 \%$ said they were not doing anything, whereas $10 \%$ stated that employee turnover within the food service industry is characteristically high, and therefore unalterable.

Table 2 of page 56 reveals how managers rated the frequency of employee reasons for leaving using $100 \%$ as base. Not surprisingly enough, employee reasons for leaving with a low rate of response included conflict with other workers and supervisor, lack of advancement and working conditions. Responses most frequently given by departing employees included finding a better job, personal reasons (school) salary and benefits.

Managers rating of responses given by their employees as reasons for leaving their establishment are reveal on 
Table 4 on page 57 . Of the managers surveyed the three positions with the highest turnover rate in their operations were cooks ( 808$)$, waiters/waitresses (608), Dishwashers $(508)$. The three positions with the least turnover were bartender $(108)$, Hostess $(20 \%)$, as shown on Table 3 on page 57 .

None of the managers on the survey was currently accumulating any data in the form of managers log that could be used to establish trends as to the causes of employee turnover in their operations. None of the managers surveyed was currently conducting a standardized exit interview where possibly, of employees leaving their restaurants.

The overall or crude turnover rate from these restaurants surveyed was around 628 . This percentage was derived by using the formula explained in a handbook on Career Ladder, the National Restaurant Association explains the formula as:

$\frac{\text { Number of replaced separations }}{\text { Average number of employees }} \times 100=$ Turnover 8 rate.

The median length of service was two months. Table 3 on page 57 list the turnover rate for each job category of the restaurants and the length of service of leavers for that category. 
The information in Table 3 was derived by managers use of employees file who had quitted.

The Job Description Index (JDI see Appendix C page 99 ) was one of the forms completed by food service employees during the survey. In it, employees responded to adjectives in the areas of work, supervision, people pay and promotion which were the most common reasons employees gave for. The causal factor of turnover "Y" put besides on item that describes the aspect of employee's job.

"N" put on items that does not describe that aspect or a question mark (?) if such phrase cannot be decided. The negatives and positives were calculated and arrived at a percentage. It was observed that pay supervision and promotion had the lowest rating.

Job Description Index (Work with job ) Percentage:

Job

$\mathrm{High}$

Low

Cook

waiter

Busboy

Dishwash

Bartender

Cocktail Waitress 
Table 6

Job Description Index (Supervision) with job. Job $\mathrm{High}$ Low

Cook

Waiter

Busboy

Dishwash

Bartender

Cocktail Waitress

Total

258

Table 7

Job Description Index (People) with job. Job High Low

Cook

Waiter

Busboy

Dishwash

Bartender

Cocktail Waitress

Total

658

Table 8

Job Description Index (Pay) with job.

Job $\mathrm{High}$

Low

Cook

Waiter

Busboy

Dishwash

Bartender

Cocktail Waitress

Total

81.58


Table 9

Job Description Index (Promotion) with job.

Job $\mathrm{High}$

Low

Cook

Waiter

Busboy

Dishwash

Bartender

Cocktail Waitress

Total

608

As indicated by the Job Description Index Pay, Supervision, and promotion have the lowest rating. Job categories and findings

The cooks as shown on Table 3 , page 57 , had $80 \%$ turnover rate. The most frequently mentioned reasons for wanting to leave their jobs was the low wages and long hours. When asked what they disliked most about their present job, most cooks responded that there was too much work load on them and too little pay. Other cooks stated that they were bothered by not having a regular work schedule and often not knowing from one day to the next what hours they would work. The researcher observed from the cooks statements that better supervision in organizations and running the kitchen was needed in three of the operations.

Waiter/Waitresses

The turnover rate was 608 and length of service 2 months. Majority of the waiter/waitresses complained of 
the inefficiency of the kitchen in getting orders out makes their jobs difficult and aggravating.

Some complained of inexperienced hostess who had been put in charge of them, others stated bad management of the dining room, some of the problems mentioned were overburdening waitresses by not seating customers in rotation, being rude to waitress or not being understanding of their point of view.

Busboys:

Turnover was 458.708 of busboys stated that they took the busing jobs because the jobs were available and they needed the money. A good number of bus personnel stated that they were treated unfairly and inconsiderate by supervisors when asked what they disliked about their present jobs, the response was that they were often treated "like kids." Some stated they don't intend to keep their jobs, but saw them as merely temporary until something better came along.

Cocktail Waitress:

The turnover rate of this category of workers was 45\%. The most complain from these workers was that management often did not hire enough help during busy times. Some complained they should be making more money.

Employees category with highest turnover rate were interviewed in this section. 
TABLE 1

Results of Survey given by employee for leaving. Total number of employees surveyed: 80 .

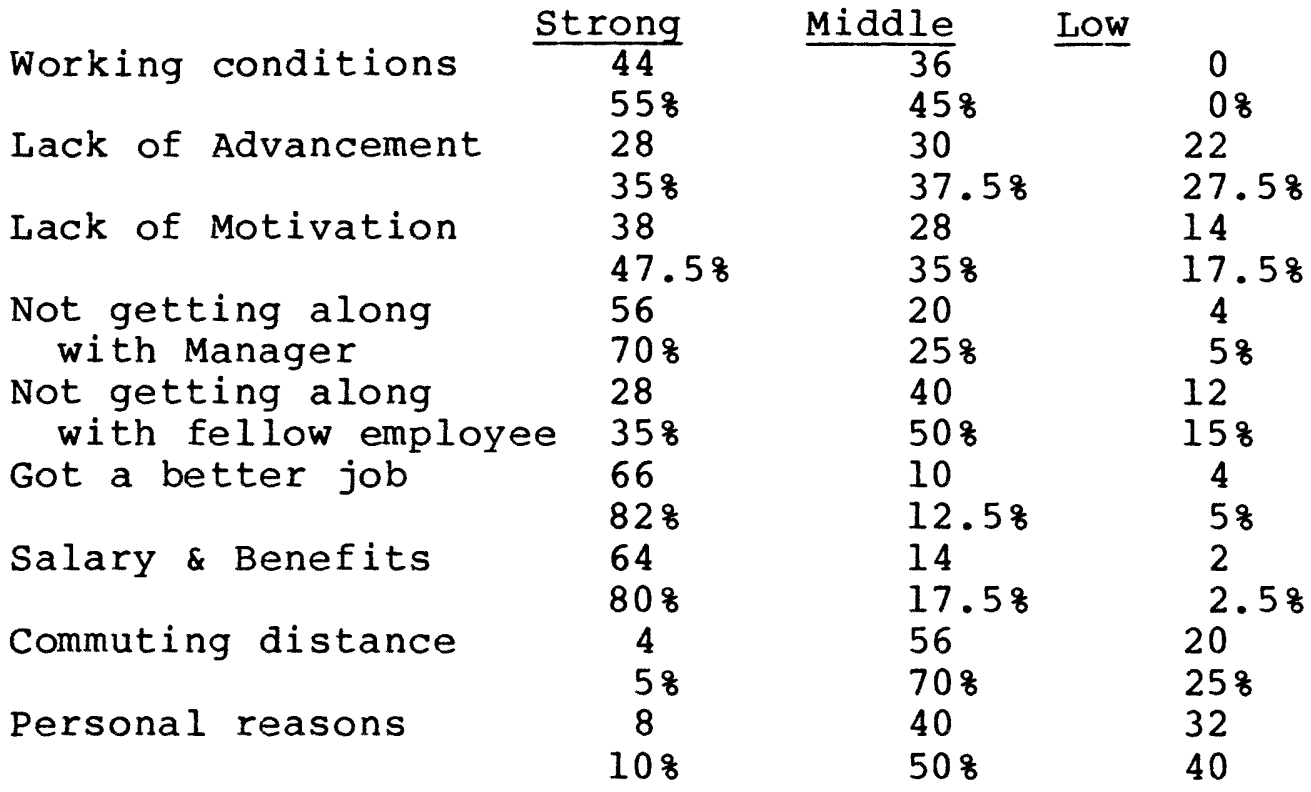


TABLE 2 leaving

Result of Survey given by Managers for employee

Working conditions 138

Lack of advancement 8

Salary and benefit 20

Conflict with supervisors 11

Conflict with other workers 8

Found a better job 20

Personal reasons (school) 20

total

1008 


\section{TABLE 3}

Turnover data for jobs categories

job

waiter/waitress

cooks

hostess

busboy

dishwasher

bartender

cocktail waitress

\section{turnover}

60

80

20

45

50

10

45 length

2 months

1 month

3 months

2 months

1 month

12 months

3 months

Table 3 reveals the six areas where turnover was occurring in these restaurants.

1008 was used in each job category and each job category turnover is based on $100 \%$. 
TABLE 4

Causal factors of employee turnover

Selection and Hiring practices

Insufficient job orientation policies

Incompatibility of employee to the job

Inadequate information/material regarding job requirement

Inadequate supervision

Lack of job training program

Inability to air grievances

Working conditions

12

Lack of advancement

5

Lack of feedback

7

Financial incentive

Low social status attached to the work performance 


\section{SECTION VI}

IMPLICATIONS / CONSEQUENCES 


\section{Implication or Consequences}

The survey reveals dissatisfaction with pay, supervision, promotion and co-workers as was seen by an employee Questionnaire and Job Description Index made to cause turnover in a particular operation. The turnover rate for the operations was 688 with a few months lengths of service. This rate of turnover with low length of service prevents the formation of a stable and cohesive work group.

The dissatisfaction apparent with the intrinsic rewards of work automatically hinders the development of work relationships that are a significant element of the intrinsic reward of labor. In this survey a large number of labor force interviewed responded negatively in their description of their pay and supervision.

Poor supervision not only influence employees attitude towards their managers but also it influenced the employees negative perceptions of work, pay and fellow workers. An example is the dissatisfaction in the kitchen is carried through to the dining room waiters/waitresses who depend on the kitchen for performing their work. Waitresses complained that their jobs were made more difficult by not being able to get satisfactory products from the kitchen and not getting the product quickly enough. 
The immediate price paid by the organization is therefore having difficulty in maintaining its standards in both production and service. Within production and service sectors, capable employees felt discouraged by a transient population of unskilled and poorly trained workers. This inefficiency not only affect the work group but also affect the customer in the quality of product and service received and therefore, by the company that depended on the satisfied customer's patronage.

Loss of customers due to inferior quality of food or service resulting from dissatisfied workers ready to quit and new and untrained employees. A lost customer can cost in terms of sales as well as the cost that dissatisfied customers can create among their friends.

Employees are demoralized during the first few weeks or months when disgruntled quitting employee are in the process of quitting and looking for another job.

The headaches, strains suffered by managerial personnel should not be overlooked where there is a constant flow of quits and replacement when the turnover is high since there are more leavings, selection standards tend to be lowered initial interviews become more perfunctory, managers begin to feel they have no time to carry out initial interviews even if allowed to do so, interviews tend to despair in their attempts to get new employees. In 
such a situation, opportunities to inhibit leaving are not taken, the number of leavers rise still further, and the situation gets worse. Under these circumstances, managers get so busy with the task of taking new employees that no one feel he has the time to take remedial action to stop the flow of leavers.

Flam Holtz has incorporated these costs into a model for measurement of human resource costs shown in the figure next page. The model has three components, the acquisition costs, the learning costs and the separation costs. The point of the model is to indicate how the cost are subset of the overall replacement cost incurred by an organization when it has labor turnover.

The need to reduce turnover does not imply that zero turnover is at all desirable is a way of losing less capable employees and for allowing room for promotion for capable employees. The emphasis is therefore to reduce turnover to the most realistic levels in terms of costs and organizational efficiency. 

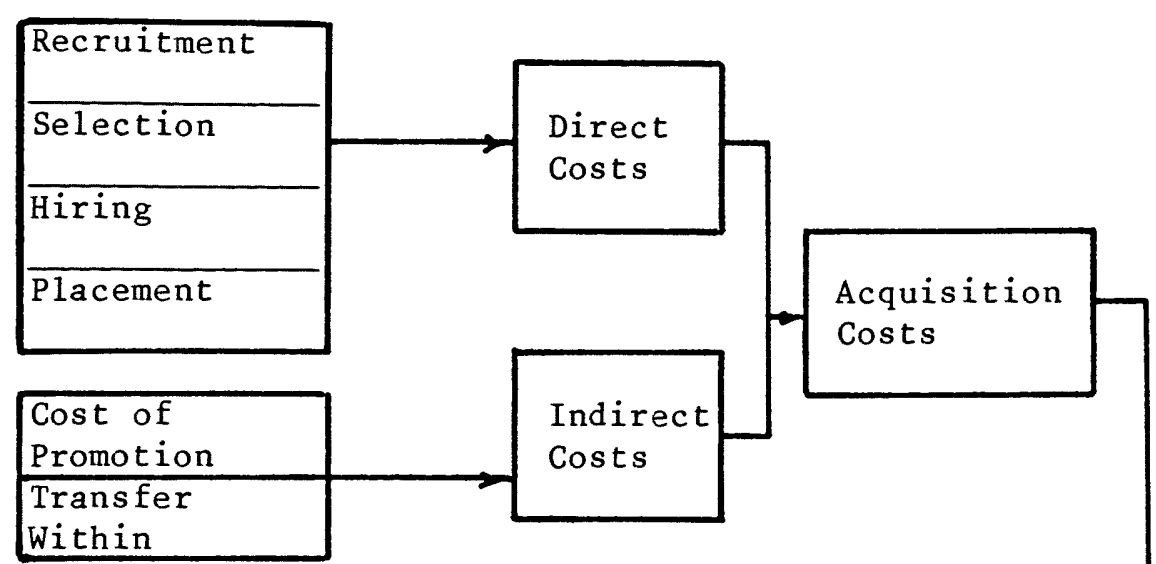

\begin{tabular}{l} 
Formal Training \\
and Orientation \\
\hline $\begin{array}{l}\text { On-the-job } \\
\text { training }\end{array}$ \\
\hline
\end{tabular}

Cost of
Trainer's
Time

\section{Indirect \\ Costs}

\section{Direct} Costs

(1)

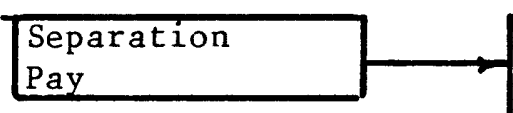

Loss of efficiency Prior to separation

Cost of Vacant Position during Search

\section{Direct} Costs
Costs

\section{Learning Costs}

Position Replacement Costs

Separation

Costs

Ind i rect

Source: Eric G. Flamholtz,"Human Resources Accounting: Measuring Positional Replacement Cost," Accounting Information systems Working Paper No.71-10, Graduate School of Management, University of California, Los Angeles, March 1971. 
There are measurable direct cost and base in areas of recruiting, selecting orientation and training new employees. Some of these direct costs include interviewing, training, orientation, additional record keeping, and reporting, telephone inquires, screening, testing and checking references. These time consuming activities have great costs involved.

The indirect cost for the hidden cost although intangible and impossible to measure, can be many a times higher than the direct costs. Frequently overtime rates are paid for other employees, as well as demoralizing over work, while replacements are being recruited, hired and trained.

Benefit

Turnover might have certain benefits and this should not be over looked. Turnover should not be reduced to zero, rather the emphasis should be on selectively controlling and manaing turnover to a point where the right people stay and marginal workers leave.

The lower average cost of labor, as an employee tenure increases so does his or her wages, while his production remains constant. Newly hired employees usually start at a lower wage scale. Displacement of poor workers, and infusion of new knowledge through replacement, and finally increase in structural flexibility. 
In an article entitled "Absenteeism and Turnover," Hawk listed the principal cost areas of tangible and intangible costs which might possibly be involved in labor turnover. These include:

(1) Lost productivity

(2) Cost of orientation and training

( 3 ) Cost of additional labor

(4) Loss of efficient production

(5) Loss through material spoilage or customer dissatisfaction.

(6) Advertising and/or employment agency expense

( 7) Employment department expense

( 8 ) Medical exam expense

(9) Cost of induction and testing

(10) Overtime premiums

(11) Cost of processing people into Payroll. 37

37 Donald L. Henk. "Absenteeism and Turnover," Personnel Journal, June 1976, p. 295. 


\section{SECTION VII}

MEASUREMENT OF EMPLOYEE TURNOVER 
Measurement of Employee Turnover

A major shortcoming in many studies of labor turnover has been the reliance on the undifferentiated or "crude" turnover rate. Two types of crude rate are needed to measure turnover. Accession to the organization and "separations" from the organization. Computations of those rates are as follows:

$\begin{array}{ll}\text { Accession rate }= & \begin{array}{l}\text { No of new members } \\ \text { added during the period }\end{array} \\ \begin{array}{l}\text { Average number of members } \\ \text { during the period }\end{array} \\ \text { Separation rate }=\quad \begin{array}{l}\text { No of new members who } \\ \text { left during the period } \\ \text { Average number of members } \\ \text { during the period }\end{array}\end{array}$

Crude turnover rates are multiplied by 100 and expressed as percentages.

This formula is used in a Handbook on Career Ladders, published by The National Restaurant Association, while thus may be an easy formula for management to use, van Der Merwe and Miller point out that a separation rate of 1008 per year could indicate the following:

(1) That the entire labor force had turned over once during the year. 
(2) That half of the labor force turned over twice, the other half remaining stable,

(3) That a quarter had turned over four times.

This labor turnover rate does not indicate where, in the length of service continum of the labor force, turnover is occurring. Van Der Merwe and Miller make the analogy between turnover rates and death rates and state that both should be handled in the same way, statistically.

"This leads to a most important proviso; namely that, since, in vital statistics, a death rate is heavily influenced by the age composition of the population the, by the same token, turnover rates will be influenced by the length of service distribution of the labor force. It is of course, well documented in labor turnover research that labor turnover rates among short service workers are invariably higher than among long service workers. What is not generally realized, however, is that if labor turnover rates vary with length of service, then an overall (or crude) labor turnover rate for a working group will be heavily influenced by the length of service composition of that group." 38

An article on personnel management of 1955. H. silock stated that the current turnover rate of a firm is more likely to depend on fast events, which have determined the length of service composition of the labor

${ }^{38}$ Van Der Merwe and Sylvia Miller. The Measurements of Labor Turnover," Human Relations, Volume 24, No. 3, p. 236 . 
force, than on current factor, such as the state of labor relations. In discussing the importance of length of service variable, Van De Marwe and Miller state that various factors influencing the employee's decision to stay or leave, act with varying strength at different times in the length of service continum. They add that the formation of group ties is very likely to be of overriding importance, particularly in the first few months of employment. Their assumption is that the major satisfactions which are likely to differentiate one job from another are those to be found in interpersonal contacts in the working group. They state that if workers' need for belonging to a cohesive and rewarding group is not satisfied, then he is unlikely to adjust to the work situation and will more readily withdraw from it. The relationship between group relationship and turnover is summarized by Van Der Merwe and Miller as follows:

"Satisfying interaction are unlikely in groups which are temporary in nature, and are constantly in a state of erosion and replacement as a result of high labor turnover satisfying group interactions then, will depend upon the existence of stable groups which are cohesive in character, and facilitate positive relationships among group members. New employees will be more easily integrated into such groups, thus providing replacements for inevitable losses among longer-service workers, and maintaining the stability of the group. By contrast, a circular effect is evident in high turnover groups, where the lack of a stable core results in poor integration of the 
newcomer, and high short-term losses, so that few pass on to become long-service workers who may provide a stable core in the future." 39

The above discussion shows labor turnover to be both a result and a cause of unsatisfactory interaction between the employee and the work group. The measurement of turnover must then include not only the extent of labor movement, but also, where, in length of service, such movement is occurring. Survival curve as a measurement of turnover.

The development of vital measures of labor turnover, may be based on the following criteria as stated by van Der Merwe and Miller:

"As the analysis of labor turnover is undertaken with a view to making management decisions, such analysis should be confined to turnover which is avoidable, and thus subject to management action. The overriding importance of the length of service variable must be considered in any analysis where appropriate, a measure should be able to compare or separate some of the effects of the interralated variables which are involved in turnover." 40

The approach towards the measurement of labor turnover, used by M.C. Knowles in 1965, includes the crude labor turnover percent read in conjunction with the median

$$
{ }_{40}^{39} \text { Ibid., p. } 239 .
$$


length of service of all leavers. The combination of data indicates the level of turnover and where, in terms of length of service, turnover is occurring. Thus, two restaurants may have similar turnover rate but differences in the median length of service of their leavers. The knowledge of the median length of service of leavers would, therefore, be important in determining the causes of turnover in each restaurant.

The median length of service is actually a measure of central tendency of a distribution of leavers. This distribution may be converted into a survival curve which would show the periods surveyed in service before a separation takes place. As described by Van Der Merwe and Miller, such curve is shown in Figure A. 
Figure A

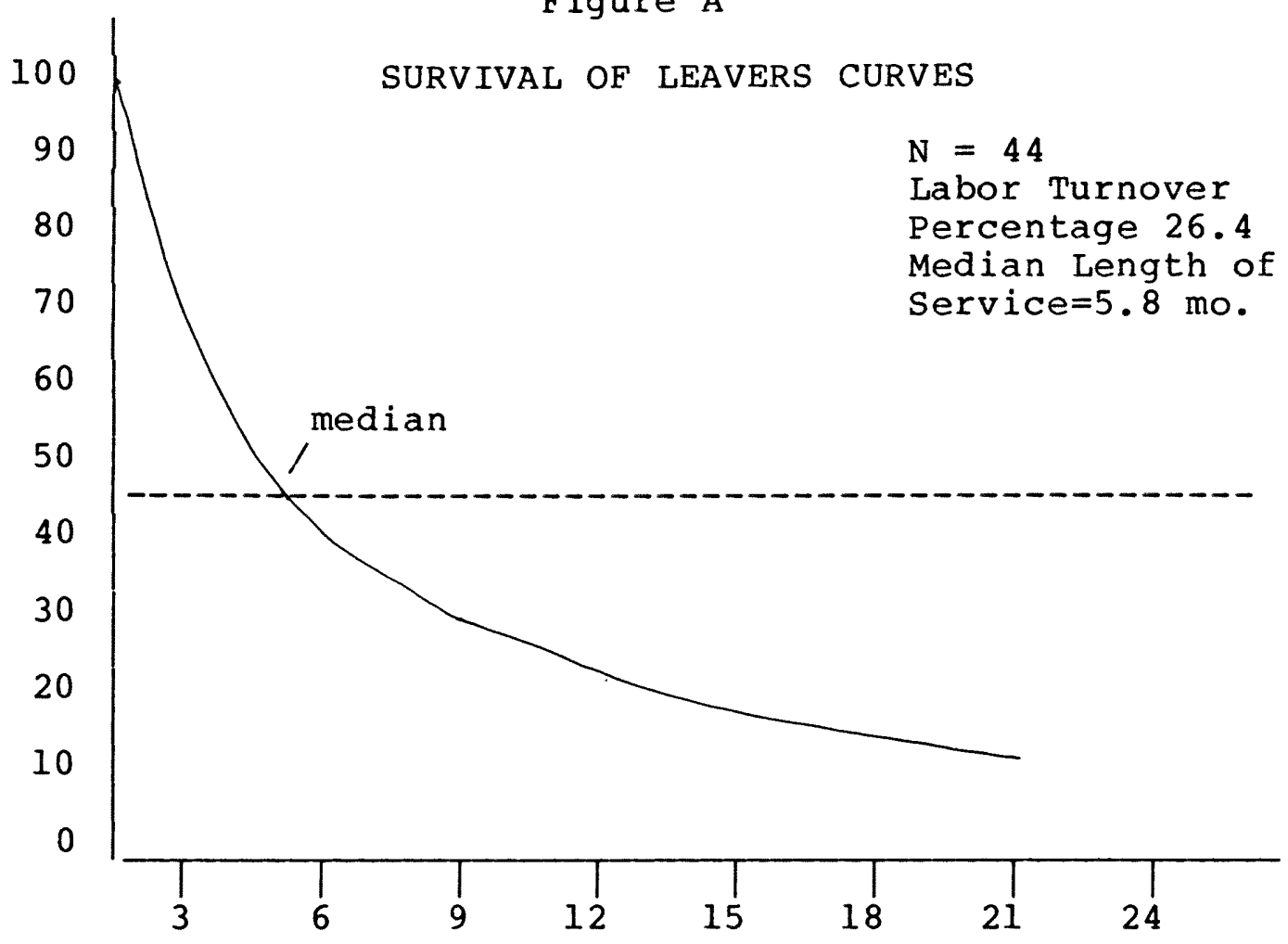

Source: R. van Der Merwe and Sylvia Miller, "The Measurements of Labor Turnover," Human Relations, Volume 24 , Number 3, p. 139.

The survival of leavers curve is related to the labor force, as a whole, by specifying the total labor turnover rate along with the curve.

"Where comparisons between two or more curves are to be made, it is even more necessary to specify labor turnover rates. Thus, those curves which are allied to higher labor turnover rates will generally be more steep [or below those curves which are allied to lower rates. Such a situation was illustrated by Rece et al (1950) in their comparison of the wastage rate curves of Glacier metal and "Factory X." The reason for this is that high turnover in the main is allied to a higher percentage of short-service persons on the 
payroll, and hence a higher percentage of short-service leavers giving rise to "steeper" or lower curves" 41

This statistical relationship such as those cited above may be usefully related to group process cited earlier. It would be expected, therefore, that losses would be most evident among integrated members of shorter service while the core or long service part of the group is stable. Should there be large losses of long service workers or a total lack of long service workers, the turnover would be high in all sectors of the work group and would be of serious proportions requiring managerial action.

It is evident that the measurement of labor turnover include both labor turnover rates and either median lengths of service or survival of leavers curve. Other interrelated variables associated with turnover may then be analyzed within the frame work of meaningful turnover measures.

Withdrawal Behavior

As stated by March and Simon, employees participation may be analyzed in terms of job behavior and job attitudes. Job behavior will include absences, level of performance, job turnover and accidents. A study of voluntary labor turnover involves the study of both withdrawal 
behavior and job attitude the researcher has decided to focus this study on the employee's decision to quit or voluntary turnover, because of the exceedingly high incidence of this behavior in the hospitality industry.

The relationship between the withdrawal behavior of turnover and absenteeism while have not yet be conclusively determined there is however, certain prevailing points of view around which most of the literature has focused. Firstly, there is a continum of withdrawal behavior, progressing from absenteeism to turnover.

Herzberg and his fellow researchers believe that:

"The problems of turnover and absenteeism may
be discussed together since in some respects
the small decision, which is taken when the
worker absents himself, is a miniature version
of the important decision he makes when he
quits the job. High absenteeism (lateness and
absence) appears to be an earlier sign, and
turnover (quitting and being fired) the dying
stage of a long and lively process of leav-
ing."42

In an article, Personal psychology (1972). Thomas Lyon sighted data supporting this point of view. 16 out of 29 independent tests of this relationship between turnover and absenteeism were significant and positive. Tavistock researchers (Hill and Trist, 1955 and Rice and Trist, 1952) saw absences, along with accident, as being forms of withdrawal behavior that are alternative to turn- 
over. They sighted ten samples of individuals who eventually quitted their jobs. Each of these individual had significantly higher records of absenteeism than those who stayed.

Another view is that the two behaviors related or not, share common causes. March and Simon (1958) state that there may be no consistent relationship between turnover and absenteeism but:

"Differences between absences and turnover stem not from differences between in the factors inducing the initial impulse but primarily from differences in the consequences of the alternative forms of withdrawal."43

Lyons further goes to say there is presently little statistical support for the notion of common correlates between turnover and absenteeism.

Job Satisfaction

Job satisfaction as used in this research means the valence or affective orientation of a work role to the person performing it (Victor Vroom, 1964). The greater

42 Frederick Harzberg, Bernavel Mausire, and Barbara Snyderman. The Motivation to Work, New York, John Whiley \& Son, Inc., 1959, p. 103.

43 Thomas Lyon, "Turnover and Absenteeism: A Review of Relationships and Shared Correlates," Personnel Psychology, Vol 25, 1972 , p. 279. 
the individual's satisfaction with the job, the less perceived desirability of movement. The point to note here is that individual workers have different attitudes and expectations in the work environment that are often shared by forces outside of the industrial setting. Brayfield and crockett warned that researchers should not assume a strong nor direct relationship between satisfaction and job performance.

P. Smith and her co-researchers found that there are five subcomponents of job satisfaction that are clearly identifiable and measurable. These are work, pay, supervision, promotion and co-workers. They developed the Job Description Index for the purpose of measuring satisfaction levels in each of these categories.

An employee's decision to stay with the establishment is seen by March and Simon in terms of an inducement-contributions balance. These balance they consider to be a function of two major components: "The perceived desirability of leaving the organization and the perceived case of movement from the organization." 44

"Increases in the balance of inducement utilities over contribution utilities decreases the propensity of the individual participant

$44 \mathrm{Victor}$ Vroom Dec (Eds), Management and Motivation, Baltimore: Penguin Books, 1970, p.108. 
to leave the organization, whereas decreases

in that balance have an opposite affect." 45

"The perceived case of movement from an organization is affected by a combination of the state of the economy the availability of outside alternatives and by the individual employee's characteristics, such as age, sex, tenure with the organization and level of skill. Dissatisfaction stimulates search and makes, movement desirable and more feasible.

\footnotetext{
${ }^{45}$ Ibid., p. 108.
} 
SECTION VIII

CONTROL STRATEGY 
Control Strategy

The control of turnover is not as simple as one might think. It requires time, study and corrective action. No single action can reduce employee turnover. It is most often caused by poor management practice and can also be controlled by a positive, sound program of good management, vigorously initiated.

The restaurant business is a combination of production and service unit. There is a combination of tasks, added to the complexity of customer on the premises initiating action by giving his order to the service personnel. These peculiarities of situation give rise to emotional tension with which certain employees can not cope. This might result to employees seeking jobs in other industries. The study reveal that food service employees feel they can readily find work within the restaurant business if there were to leave their present job. Under such conditions, it is pertinent therefore to note that intrinsic and extrinsic rewards specific to their present jobs takes on a greater role in keeping the employees at these jobs.

An individual decision to stay or resign as stated by Victor Vroom, is determined by the valence of his present position. The valence of other positions and the expectancy that the other position can be attained. Since the 
expectancy is $\mathrm{high}$ and since restaurant business actively seek to attract competent and dependable labor, then Vroom's statement becomes heavily weighted on the valence of food service employees. From the study it is observed that most food service employees are attracted to their present jobs because jobs were available, the jobs were seen as not boring, as opposed to other alternative jobs, third flexibility of hours, they could work days, nights or split shifts, pay and benefit were acceptable. Dissatisfaction with the jobs occurred when employees were overworked, did not get the hours they wanted and not competent supervisors and co-workers with whom to perform their jobs.

Management should therefore pay close attention to the causes of dissatisfaction in the job environment. The reduction of job dissatisfaction and of the quitting resulting there in will create a more than stable and efficient work group which will be more productive for the employer and more so intrinsically rewarding for the employee.

Turnover therefore be reduced and controlled, only in terms of its causes. Manager's more often attribute excessive turnover rates solely on exterior influences and conditions in the labor market, i.e. the kind of people we employ or low wages paid, these factors to a degree con- 
tribute to the problem, more often than not there are other causal factors which are controllable by management.

Another fallacy is the acceptance of the reason that worker gives for quitting, which in most cases is not the real reason. The "quit" often tend to offer good reasons for quitting rather than the real reason. It is pertinent to mentioned some of the causal factors here so that control methods can be followed.

Mis-employment. Management failure to match the individual to the job properly accounts for more than half of all employee turnover. From the study it is observed that a great number of turnover occurred during the first 30 days of employment (See Table 3 ). These facts suggest either the worker was mis-matched or mis-employed or the worker was improperly oriented and trained to do the job.

\section{Solution}

Every organization should have proper method place people to jobs with good orientation and training, thus avoiding waste of manpower. Management should establish and maintain a sound employment program, should know what to look, and where to look, get a number of applicants and select the best. Get facts, check references, study applications, select applicants best qualified and introduce new employees to the job properly. Provide job breakdown 
for all jobs, training guide lines and see that those in charge of training know how to train and have the necessary time to do it.

\section{Inadequate and Ineffective Supervisor}

It is a well known fact that when supervision is lacking with no good leadership qualities, workers flounder, lack direction and a sense of purpose, become indifferent, dissatisfied and the result is quitting. Most often than not, failure of the food service industry to establish and maintain adequate and effective supervision is a major contributing factor to the industries excessive employee turnover.

Solution

Effective and adequate supervision should be established. Monthly or quarterly, performance standards can be reviewed, discussing the ratings with each worker. Recognition be given to outstanding performance either in writing, verbally or through monetary compensation wherever possible employees self-respect should not be abused by management. Employees should be viewed as part of the organization and as persons with individual sentiments, feelings, aspirations and emotional needs.

Pay plays a very vital role in turnover among food service employees, and should be taken seriously. Successively fair pay will probably produce successively 
lower turnover. Pay refer to money and other fringe benefits that have financial value which the establishment gives to its employees in return for their service. Although pay is not equivalent to satisfaction with pay. Satisfaction with pay is the member's social psychological response to the amount of money received, while pay is the money directly received. Pay is therefore objective variable, satisfaction with pay subjective variable successively fair pay in most instances probably produces high amount of satisfaction with pay.

Solution

Employees should know his pay, why he is paid the amount; at least be made to understand it is fair and equitable. Many a times, managers ignore employees in the food service industry when they complain of pay. Pay, as we know, is a symbol of social status in the community, workers who feel they are not well paid tend to become hostile and quit or stay with reduction in productivity. Employees should be made to know the framework of the organization's wage scale. Evaluation of jobs should be made and assurance of prevailing rates be paid where possible, equal pay treatment for equal work.

Lack of social identification makes workers feel rejected by his co-workers and thus lessen such workers productivity. 


\section{Solution}

Successively higher integration will produce lower turnover. Integration is the extent of participation in primary or quasi primary group management should see that employees share common interest, purposes which are of both interest to the organization as well as to the individual. It is the duty of management to match employees with compatible work group.

Encourage employees to participate, give them information concerning the operation and solicit their suggestions and ideas. Let them become involved in a team atmosphere. This can be carried out through employee meetings, thus building group enthusiasm and team spirit.

Instrumental and formal communication when lacking turnover increases in the establishment. Communication is the process of the transmission of information to the employees.

Solution

Management should study its turnover, its causes, keep and study records. Management should define and communicate to employees its philosophy. Formulate, publish, distribute and explain regularly personnel policies, rules, regulations and procedures, which will keep employees abreast with policies in the organization. 
Managers can also establish ways of relating to the employee, by so doing, management can make the pains of joining and staying more bearable. Intensive, often ended, and confidential interviews could be conducted with employees at various stages in their service. The experience of new employees can be studied throughout this engagement and induction, to discover something of the personal reality and to find out in detail how stresses were caused and experienced.

Managers should be in a position to hire selected people in their department by being continuously involved in the process of selection and induction in their department. New employees will therefore be handled by such managers to whom he was responsible, from the point of application through the early weeks or months of working. Managers would feel a greater sense of responsibility for the new employee, and the new employee could at least regard himself as having been personally chosen by the person responsible for his work. When there is a clear and consistent responsibility for the individual employee, the chances for his staying are much greater.

Erick Flamholtz, in his articles on Human Resources Accounting, quotes Pensie Wert as stating the following:

\footnotetext{
"Because of the failure of financial statements to reflect the cost of value of people, some managers may actually be encouraged to
} 
put pressure on their subordinates for increased short-term productivity, while in turn, over the long run, this may result in deteriorating employee attitudes, decreased motivation, decreased productivity, and an increase in the probability of people leaving. In effect, the manager may be encouraged to trade short-term profitability for long-term depletion in assets." 40

workers do not quit for only logical reasons. Employees decision to quit can be due to a variety petty and trivial irritants and frustration. Management should therefore know its staff and the conditions under which they work to be able to pass judgements on the stresses to which they may be subjected.

Management take a good deal of time keeping track of inventory, material resources etc. Keeping good control system, unfortunately, little is known about their greatest resource, their employees, who actually do the work. The only area where management take cognizance of employee is the area of payroll and labor cost.

Management should endeavor to have proper, complete and accessible personnel records and inventory of its employees.

Exit interviews can help in controlling employee turnover, although it requires time, patience, and skill.

40 Eric Flamholtz, Human Resources Accounting, Measuring Cost of Turnover, 1972, p.6. 
Although this might be cumbersome because departing workers most often than not do not usually give real reasons for quitting. In most cases, quitting employees reason might be against management in areas of pay, working condition, supervision to mention a few, but this employees under this situation are reluctant to say so due to the fact that they might use their supervisors for references. Management can be tactful by using exit interview by impartial individuals, eg. a friend of the departing employee of whom he would feel free to state his mind. Information derived through exit interviews can be beneficial to management because it is very reliable and thus remedial measures can be taken. 
XYZ RESTAURANT

Exit Interview Report

Employee Name

Date employed

Position held while at XYZ RESTAURANT

Present position

Type of separation (check one)

(a) quit, (b) layoff, (c) terminated, (c) other Employee reason for leaving:

Manager's statement of reason for leaving:

Employee's evaluation appraisals

Has employee found a new job? (Yes)(No)

If yes, what is his new position

Is his present position more attractive? (Yes)(No)

If employee has not found a new job, what are his plans?

Manager's signature 
The questionnaire can be used along with a selfaddress stamped enveloped. After time has lapsed, so that the initial anger that caused the employee must have subsided and he must have got another job and feels secured at this point a more honest evaluation can be obtained. If the former employee decides to return the questionnaire favorable results can be obtained, but this method can be looked with a grain of salt, because the questionnaire can be dumped in the waste paper basket.

A close examination of quits and those who have stayed with the establishment can give management some information about the different characteristics between the two. This information could help managers in hiring and selection.

The survey indicates that cooks and waiter/waitresses have the highest turnover rate in these restaurants. Management could, therefore be very careful in hiring people in these categories. The study also indicates that most of the turnover takes place the first 60 days of employment, management should therefore concentrate on the employment policies and effect changes.

Experience might play a role in "quits." It might be observed that workers most likely to stay are those with more experience in that particular job, or vice versa. Most often than not, the majority of "quits" are marginal 
87

performers. If so why were there marginal, may be the training is poor. If so, corrective measures should be implemented. Look at the working conditions, supervision, promotion, recognition and motivational aspects of the establishment. In many cases, some of these reasons vary from one establishment to another. Mangers should be in a position to know which one affects their operation most. 


\section{Summary Recommendations Conclusion and Suggestion}

\section{for Future Research}

Summary

The study was on the causes of food service employee turnover in five selected theme restaurants in the Miami area, namely, Viva Zapata, Miracle Mile, Coral Gables, The Round Table, South Dixie Highway, Dalt's, Kendall Drive, Raffles, Dadeland, and T.G.I.Friday's, The Falls. The study revealed among other factors, dissatisfaction with pay, supervision, work, promotion and co-workers at significant enough levels, as determined by an employee management questionnaire, and employee job description index, to cause turnover in these restaurants.

The kitchen staff, commented of their work not being properly organized. They felt overworked and the kitchen was poorly staffed in both quantity and quality of help. The factors causing dissatisfaction in the kitchen was carried through to the dinning room staff who depended on the kitchen for performing their work. It was agreed that turnover existed in all the restaurants surveyed from the responses. The overall or crude turnover rate for these restaurants was around $62 \%$ with a median length of service of two months.

Positions with the highest turnover rate was cook ( $80 \%)$, waiter/waitresses (608), dishwashers ( 508$)$. Positions with the lowest turnover were: bartender (10\%), 
and hostess $(20 \%)$. None of the managers in the survey was currently accumulating any data in the form of managers log that could be used to establish trend as to the causes of employee turnover in their operation. None of the managers surveyed was currently conducting a standardized exit interview where possible, of employees leaving their restaurant.

The position of managers regarding the rate of employee turnover within their operation compared to the industry average was mixed, $15 \%$ surveyed stated their rate was above average, $40 \%$ average, $35 \%$ below average, while $10 \%$ did not respond to this question. Of the managers surveyed a greater percentage stated that they are taking steps to monitor the turnover rate. Others stated that employee turnover within the food service industry is characteristically high and therefore unalterable.

Food service employees rating of the causal factors with the lowest impact of turnover were co-workers, commuting distance, and advancement. The rating of causal factors with the highest impact on turnover as stated by employees were to obtain a better job, pay and benefit, supervision and working condition.

Managers rating of the causal factor with the lowest impact on employee turnover included, co-workers, lack of advancement and conflict with supervisors. Factors with 
the highest impact according to managers was personal reasons (school) found a better job, salary and benefit.

In general, the problem of employee turnover is multifaceted in nature. Efforts to control turnover were found to be those which built and sustained job satisfaction in the work force.

Recommendation

It is pertinent to note that each restaurant has its own "personality" based in part on the management and staff which comprise each unit. Procedures which work well in one restaurant may not necessarily work in another.

Once the need is established, that a program directed at controlling employee turnover is needed, it must be tailored and applied with individual care by management.

For this study the complains revealed by food service employees reflect the interrelated nature of the area of work. Supervision, co-workers and pay in influencing job satisfaction. A skilled kitchen manager, for example, should organize work so that it could be done more efficiently and easily. The hours of work could be reduced by better organization of work and/or more competent workers, resulting in pay being perceived as more equitable. Satisfactory working conditions and pay would reduce turnover in workers remaining on the job long enough to become more proficient. 
The quality of work life in the food service industry plays a significant role in an employee's decision to stay in a particular job. This is an important factor in an industry which is rapidly expanding and competing for employees. The costs of high labor turnover to an organization, as pointed out in this study are perhaps greater than management often realize.

An article on The Wall Street Journal entitled "Quality of work life: A New Page for the Corporate Annual Report?" Getward Lawler is quoted as saying: .

"Companies should publish data about the kind of life they provide for their employees. Initial reports could include data on turnover, absenteeism, industrial accidents and illness." 47

Management must pay close attention to the causes of dissatisfaction in the job environment. The reduction of job dissatisfaction and of the quitting that may result from it will create a more stable and efficient work group which will be more productive for the employer and more intrinsically rewarding for the employee.

The results of the research instruments show that management must look at the industrial job categories in attempting to analyze the controllable turnover problem.

47 Quarterly of work Life, A New Page for the Corporate Annual Report?," The Wall street Journal, February 3, 1976, p.l. 
It is within the particular work group that the problems influencing the individuals to quit their job arise in order for labor turnover to be reduced the control strategy has been enumerated in section VIII of this study. The researcher will therefore refer management to section VIII of the study.

Conclusion

The rate of turnover in this study with such a low median length of service, prevents the formation of a stable and cohesive work group. The dissatisfaction apparent with the extrinsic rewards of work hindered the development of work group relationship that are a significant element of the intrinsic rewards of labor.

In the study, 758 of the employees responded negative$1 y$ in their description of supervision, $81.25 \%$ to pay, $60 \%$ to promotion.

The comments noted concerning supervision, pay, promotion in the job description index reveals a particular source of employee dissatisfaction in the restaurant. Poor supervision influenced not only the employee's attitudes toward their supervisors, but also influenced employee's negative perception of work, pay and co-workers.

The immediate price being paid by the organization in the study was that of having difficulty in maintaining its standards in both production and service. A lack of coor- 
dination within and between these two sectors resulted in employees feeling frustrated by working hard, yet not having their efforts yield satisfactory results. The inefficiency of a large population of short term employees was felt not only by the work group itself, but by the customer in the quality of product and service received and therefore, by the company, who depended on the satisfied customer's patronage.

The study concludes that with all the negatives effects of turnover, none of the managers surveyed kept records of number of employees leaving their operation and reasons as to established a trend to solve the problem. Therefore, it appears that management is either unaware of the negative effects of employee turnover or they have accepted high rates of turnover as a normal fact of doing business.

Suggestions for the Future

The need remain for continued research on withdrawal behavior within the specific conditions in the food service industry, more research should be done on the individual employee in the context of the food service organization. This research should precede on two levels. Firstly, improvements should be made on experimental designs with complete controls for the variables under 
study. Variables in the work situation must be experimentally manipulated and changes in withdrawal behavior, both in attendance rates and turnover, should be recorded and compared to control groups.

Secondly, attention should be paid to withdrawal process of food service employee. The sociological and psychological process which lead to the decision to withdraw should be given attention.

The behavior of the work group and of the individual employee should be studied and the forces that each exerts on the other must be analyzed as to develop greater knowledge about food service employee turnover. 


\section{SECTION IX}

SUMMARY RECOMMENDATIONS CONCLUSION

AND SUGGESTIONS FOR FUTURE RESEARCH 
APPENDIX 
APPENDIX A

Name:

Restaurant: EMPLOYEE QUESTIONS

Position:

1. How many food service jobs have you voluntarily left on your own for the last three years?

2. What was the reason for your leaving the last food service job:

3. How many jobs have you involuntarily left either terminated or dismissed? , Why?

4. What factors do you consider essential in making you want to stay in a particular food service job:

5. What factors do you feel might make you leave your job?

6. What one aspect do you like best about your job:

7. What do you think are the reasons for high employee turnover? Answer on a scale of 1 to 5 ( 1 low degree)

( 5 highest degree)

$\begin{array}{lllllll}\text { a. working conditions } & 1 & 2 & 3 & 4 & 5 \\ \text { b. lack of advancement } & 1 & 2 & 3 & 4 & 5 \\ \text { c. lack of motivation } & 1 & 2 & 3 & 4 & 5 \\ \text { d. not getting along with manager } & 1 & 2 & 3 & 4 & 5 \\ \text { e. } & \text { not getting along with coworkers } & 1 & 2 & 3 & 4 & 5 \\ \text { f. get a better job } & 1 & 2 & 3 & 4 & 5 \\ \text { g. salary and benefits } & 1 & 2 & 3 & 4 & 5 \\ \text { h. commuting distance } & 1 & 2 & 3 & 4 & 5 \\ \text { i. personal reasons } & 1 & 2 & 3 & 4 & 5 \\ \text { j. } & \text { other - specify } & 1 & 2 & 3 & 4 & 5\end{array}$


APPENDIX B

Name:

Restaurant: MANAGER'S QUESTIONNAIRE

Position:

1. Do you agree that food service employee turnover is a problem in your restaurant? (Yes) (No) (circle one) If yes, how?

2. How many individuals do you currently employ in your restaurant?

3. How many positions do you have open in your restaurant now?

4. Do you consider the turnover rate in your restaurant (a) above average, (b) average, (c) below average?

In your opinion, what do you think is the industry percentage of turnover?

5. Do you motivate your employees as a step to reducing turnover? If yes, how. If not, why?

6. Are you presently taking steps to monitor the turnover rate? (Yes) (No). If yes, what steps. What percentage rate_. If no, in your opinion, what is the rate? 
7. Which position do you feel has the highest turnover rate? (a) waiters/waitresses, (b) cooks, (c) bartenders, (d) dishwashers.

8. Which position do you feel has the lowest turnover rate? (a) waiter/waitresses, (b) cooks, (c) bartenders, (d) dishwashers.

9. What do you think are the reasons for high employee turnover. Please check on a scale of 1 to 5,1 being the lowest degree of frequency, 5 the highest.

$\begin{array}{lllllll}\text { a. } & \text { working conditions } & 1 & 2 & 3 & 4 & 5 \\ \text { b. } \quad \text { lack of advancement } & 1 & 2 & 3 & 4 & 5 \\ \text { c. } \quad \text { lack of motivation } & 1 & 2 & 3 & 4 & 5 \\ \text { d. } \quad \text { not getting along with managers } & 1 & 2 & 3 & 4 & 5 \\ \text { e. } \quad \text { not getting along with co-workersl } & 2 & 3 & 4 & 5 \\ \text { f. } \quad \text { got a better job } & 1 & 2 & 3 & 4 & 5 \\ \text { g. } \quad & 1 & 2 & 3 & 4 & 5 \\ \text { h. } \quad & \text { colary and benefits } & 1 & 2 & 3 & 4 & 5 \\ \text { i. } & \text { personal reasons } & 1 & 2 & 3 & 4 & 5 \\ \text { j. } & \text { other - specify } & 1 & 2 & 3 & 4 & 5\end{array}$

10 What do you feel would prove beneficial in reducing the employee turnover? Check on a scale of $1-5,1$ being the lowest and 5 the highest degree considered important.
a.
hiring and selection
$\begin{array}{lllll}1 & 2 & 3 & 4 & 5\end{array}$
b.
working conditions
$\begin{array}{lllll}1 & 2 & 3 & 4 & 5\end{array}$ 


\begin{tabular}{|c|c|c|c|c|c|c|}
\hline c. & leadership style & 1 & 2 & & 3 & 4 \\
\hline d. & upward and downward communication & & 2 & & 3 & \\
\hline e. & employee benefits & 1 & 2 & & 3 & 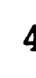 \\
\hline f. & advancement and growth & 1 & 2 & & 3 & \\
\hline g. & motivation & 1 & 2 & & 3 & 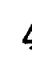 \\
\hline h. & other - specify & 1 & 2 & & 3 & 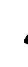 \\
\hline
\end{tabular}

11 What formal channels of communication do you use with your employees?
a. staff meetings
b. suggestions
c. grievances procedures
d. personal evaluation
e. counseling opportunities
f. other - specify

12 Any other comment as to what you feel can be done to reduce food service employee turnover in your restaurant? 
Name

APPENDIX C

Restaurant:

Position :

INSTRUCTIONS:

Put a "Y" beside an item if it describes the particular aspect of your job.

Put a "N" if the item does not describe that aspect, or a "?" if you cannot decide.

WORK

Fascinating

Routine

Satisfying

Boring

Good

Respected

Hot

Pleasant

Useful

Tiresome

Heal thful

Challenging

on your feet

Frustrating

Endless

Gives sense
SUPERVISION

Asks my advice

Hard to please

Impolite

Praises good work

Tactful

Up-to-date

Doesn't supervise

Quick-tempered

Tells where I stand

Annoying

stubborn

Knows job well

Bad

Intelligent

Leaves me on my own

Around when needed of accomplishment

$\underline{P A Y}$

Income adequate for normal expenses Satisfactory profit sharing

Barely live on income

Bad

Income provides luxuries

Less than I deserve

Highly paid

Underpaid

PROMOTIONS

Good opportunity

for advancement

opportunity somewhat

limited

Promotion on abilities

Dead-end job

Good chance for

promotion

Infrequent promotions

Regular promotions

Fairly good chance for promotions 


\section{BIBLIOGRAPHY}

Bassett, G.A. "A Study of Factors Associated With Turnover of Exempt Personnel." Croftonville, New York: Behavioral Research Service General Electric Company, 1967.

Ellen, F. Jackofsky and Lawrence H. Peters. "The Hypothesized Effect of Ability in the Turnover Process." The Academy of Management Review, 1982.

Falcion, L. Raymond. "Credibility qualifier of subordination Participation." The Journal of Business Communication, Spring 1973.

Farrell, Thomas. "Front office Communication old and New." The Cornell Quarterly, May 1973.

Fleishman, Edwin A. and Gelwin Harris. "Pattern of Leadership Behavior Related to Employee Grievances and Turnover." Personnel Psychology, Spring 1962.

Hays, R. Carl. "Dialogue Translate to Less Turnover." Restaurant and Institution, December 15, 1982.

Hume, Scott. "Must Job Hopping Remain the Common Way to Advance." Restaurant and Institutions, January 1, 1983.

Knowles, Moe. "Personal and Job Factors Affecting Labor Turnover." Personnel Practice Bulletin, 1964, 20.

Lawler, Edward. "Motivation in Work organization." Monterrey, CA, Brook/Cole, 1975.

Lyons, Thomas. "Turnover and Absenteeism: A Review of Relationships and Shared Correlations." Personnel Psychology vol.25, 1972 .

Pettman, O. Barrie. "Labor Turnover Retention." John Wiley \& Sons, New York, 1975.

Peskin, B. Dean. "The Doomsday Job The Behavioral Analyze of Turnover." Amacom. A Division of American Management Association. 1973.

Porter, L. W. and Steers, R.M. "Organizations Work and Personal Factors in Employee Turnover and Absenteeism." Psychological Bulletin, 1973. 
Price, L. James. "The Study of Turnover." The Iowa state University Press, Iowa 50010. 1977.

Price, James and L. Meuller, W. Charles. "Professional Turnover: The Case of Nurses" S.P. Medical and Scientific Books, New York, 1981.

Falcione, Raymond L. "Credibility Qualifier of Subordinate Participation." The Journal Business Communication, Spring 1973.

Roseman, Edward. "Managing Employee Turnover: A Positive Approach." Amacom, A Division of American Management Association, New York, 1981.

Sharma, J.M. And G. R. Carnabem. "Revolving the Middle Management Dilemma." Personnel Administrator, March-April 1973.

Sherwin, Douglas D. "Strategy for Winning Employee Commitment." Harvard Business Review, May-June 1972 .

Sheppard, D. "Relationship of Job satisfaction to Situational and Personal Characteristics of Terminating Employees." Personnel Journal, October 1967 .

Scott, R. D. "Job Expectancy - An Important Factor in Labor Turnover." Personnel Journal, May 1972.

Smith, Patricial, Kenadl, Lorne; and Hulm, Charles. "The Measurements of Satisfaction in work and Retirement," Chicago: Rand McNally, 1969.

Tannerbeam, Robert and Fred Marsank. "Sherma Decision Making with Subordinate." Human Relations in Administration. Edited by Robert Dubin, New Jersey: Prentice-Hall, Inc. 1968.

Van Der Merwe, R., and Miller, Sylvia. "The Measurements of Labor Turnover." Human Relations, Vol. 24, No. 3. 1978 .

Whyte, William Foote. "The social structure of the Restaurant." The American Journal of Sociology, Vol. 54, June 1954 .

Wickert, R. Frednick. "Turnover and Employee Feelings of Ego Involvement in Day to Day operations of a Company." Personnel Psychology, summer 1951. 


\section{REFERENCES}

"A Study of Career Ladders and Manpower Development for Nonmanagement personnel in the Food service Industry." Office of Manpower Research, U.S. Department of Labor, June 1970.

National Restaurant Association, "How to Invest in People." A Handbook on Career Ladder. Chicago, 1873 .

Restaurant and Institution, December 15, 1982, p. 20 .

Ibid., January 1983.

American Hotel and Motel Association. "Labor Turnover in the Lodging Industry," New York, 1973.

"Turnover and Completency." Management Review. Vol. 71, Number 10, October 1982, p. 61.

Industrial Labor Related Review, Volume 36, Number 2, January 1983, p. 239-50.

"Managing Employee Turnover, Why Employee Leave." Cornell Quarterly, February and May 1983.

James Keiser and Elmer Kallio. "Controlling and Analyzing Cost i Food Service Operation," p. 36.

"Knowing when to Leave." Management Review. Volume 71, Number 8, August 1982, p. $\overline{5-6}$.

Ibid., October 1982, p.6. 
Qualifications of the Researcher

Anthony Odey Agbeh was born in Egbe Mbube Ogoja, Nigeria, on January 12, 1957.

He attended Saint Patrick's School Egbe Mbube, where he did his elementary education.

After elementary school, he was admitted to Maryknoll Secondary School, where he obtained his west African School Certificate and Higher School Certificate in 1973 and 1975 respectively.

In 1976, he secured a job with the Board of Internal Revenue Cross River State. In January of 1978, he obtained a job with the Federal Audit Department, Lagos.

In September, 1978, he proceeded to the United States for further studies. His first school was College of Boca Raton. He later transferred in 1979 to Palm Beach Junior College, where he received an Associate Degree in Hotel \& Motel Management, in December, 1980.

In January, 1981 , he transferred to Florida International University, where he received a Bachelor of Science Degree in Hotel Motel Management in August 1982.

In September 1982, he started his Master's Program at Florida International University. He will receive his Master of Science Degree in Hotel and Food Service Management in December 1983. 